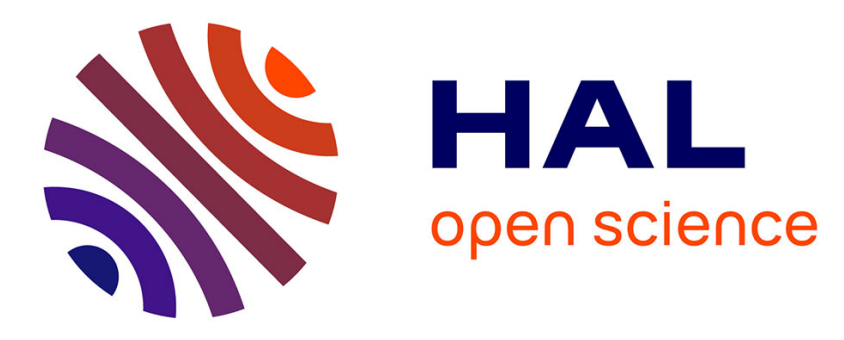

\title{
Targeted Magnetic Intra-Lysosomal Hyperthermia produces lysosomal reactive oxygen species and causes Caspase-1 dependent cell death
}

\author{
Pascal Clerc, Pauline Jeanjean, Nicolas Hallali, Michel Gougeon, Bernard \\ Pipy, Julian Carrey, Daniel Fourmy, Véronique Gigoux
}

\section{To cite this version:}

Pascal Clerc, Pauline Jeanjean, Nicolas Hallali, Michel Gougeon, Bernard Pipy, et al.. Targeted Magnetic Intra-Lysosomal Hyperthermia produces lysosomal reactive oxygen species and causes Caspase-1 dependent cell death. Journal of Controlled Release, 2018, 270, pp.120-134. 10.1016/j.jconrel.2017.11.050 . hal-02319530

\author{
HAL Id: hal-02319530 \\ https://hal.science/hal-02319530
}

Submitted on 18 Oct 2019

HAL is a multi-disciplinary open access archive for the deposit and dissemination of scientific research documents, whether they are published or not. The documents may come from teaching and research institutions in France or abroad, or from public or private research centers.
L'archive ouverte pluridisciplinaire HAL, est destinée au dépôt et à la diffusion de documents scientifiques de niveau recherche, publiés ou non, émanant des établissements d'enseignement et de recherche français ou étrangers, des laboratoires publics ou privés. 


\section{OATAO \\ Open Archive Toulouse Archive Ouverte}

\section{Open Archive Toulouse Archive Ouverte (OATAO)}

OATAO is an open access repository that collects the work of Toulouse researchers and makes it freely available over the web where possible

This is an author's version published in: http://oatao.univ-toulouse.fr/24543

Official URL: https://doi.org/10.1016/j.jconrel.2017.11.050

\section{To cite this version:}

Clerc, Pascal and Jeanjean, Pauline and Hallali, Nicolas and Gougeon, Michel and Pipy, Bernard and Carrey, Julian and Fourmy, Daniel and Gigoux, Véronique Targeted Magnetic Intra-Lysosomal Hyperthermia produces lysosomal reactive oxygen species and causes Caspase-1 dependent cell death. (2018) Journal of Controlled Release, 270. 120-134. ISSN 0168-3659

Any correspondence concerning this service should be sent to the repository administrator: tech-oatao@listes-diff.inp-toulouse.fr 


\title{
Targeted Magnetic Intra-Lysosomal Hyperthermia produces lysosomal reactive oxygen species and causes Caspase-1 dependent cell death
}

\author{
Pascal Clerc $^{\mathrm{a}, \mathrm{b}}$, Pauline Jeanjean ${ }^{\mathrm{a}, \mathrm{b}}$, Nicolas Hallali ${ }^{\mathrm{a}}$, Michel Gougeon ${ }^{\mathrm{c}}$, Bernard Pipy ${ }^{\mathrm{d}}$, \\ Julian Carrey $^{\mathrm{a}}$, Daniel Fourmy ${ }^{\mathrm{a}, \mathrm{b}}$, Véronique Gigoux ${ }^{\mathrm{a}, \mathrm{b}, *}$ \\ a Laborataire de Physique et Chimie des Naro-Objets, CNRS UMR5215-INSA, Universiv de Toudause III, Taulotse, Prance \\ b INSERM ERL1226, Receprology and Tareted Therapy of Concers, Toulouse, France \\ 'Univerdte de Toulouse 3/CNRS, CIRMAT, Toulouse, Frarce \\ d UMR 152-Pharma-Dev, Universite de Toulouse, 31432 Toulouse, Prance
}

\section{A R T I C L E I N F O}

Regwords:

Cell death

Cancer

Casprase-1

Magnetic hypenthermia

Lysosome membrane permeabilization

Cothepsin-B

\begin{abstract}
A B S T R A C T
Therapeutic strategies using drugs which cause I.ysosomal Cell Death have been proposed for eradication of resistant cancer cells. In this context, nanotherapy based on Magnetic Intra-l.ysosomal Hyperthermia (MILH) generated by magnetlc nanoparticles (MNPs) that are grafted with ligands of receptors overexpressed in tumors appears to be a very promising therapeutic option. However, mechanisms whereby MILH induces cell death are still elusive. Herein, using Gastrin-grafted MNPs specifically delivered to lysosomes of tumor cells from different cancers, we provide evidences that MIIH causes cell death through a non-apoptotic signaling pathway. The mechanism of cell death involves a local temperature elevation at the nanoparticle periphery which enhances the production of reactive oxygen species through the lysosomal Fenton reaction. Subsequently, MIIH induces lipid peroxidation, lysosomal membrane permeabilization and leakage of lysosomal enzymes in to the cytosol, including Cathepsin-B which activates Caspase-1 but not apoptotic Caspase-3. These data highlight the clear potential of MILH for the eradication of tumors overexpressing receptors.
\end{abstract}

\section{Introduction}

Cancer is a leading cause of death with millions of new people di agnosed with cancer every year. One major reason that limits outcome and drug response of anti cancer therapies is multidrug resistonce [1]. However, recent studies have shown that cancer cells resistant to tra ditional therapies can be sensitive to agents which induce lysosomal cell death through lysosome membrane permeabilization (LMP) [2]. In fact, LMP can be triggered by a wide variety of stimuli including death ligands, oxidative stress and treatment by lysosomotropic agents [3]. In some circumstances (i.e. treatment by lysosomotropic agents), LMP appears to be an early event triggering apoptosis whereas in others (i.e. treatment by death ligands), LMP results from the activation of apop tosis signaling pathways and contributes to the amplification of death signals.

Alternatively to these above agents, we [4] and others [5,6] have recently proposed that Magnetic Intra Lysosomal Hyperthermia (termed MILH), induced by application of a high frequency alternating magnetic field (AMF) to cells containing magnetic nanoparticles (MNPs) in their lysosomes, is an effective way to specifically trigger lysosomal cell death in cancer cells [7]. This is the result of the heat released by MNPs when exposed to AMF. Moreover, MNPs offer the potential to be driven into lysosomes of tumor cells by grafting them with ligands or antibodies that recognize receptors overexpressed in tumors. Subsequently to their activation, receptors are internalized together with ligand grafted MNPs and traffic to lysosomes [4,5]. Using this strategy, we showed that minute amounts of iron oxide MNPs targeting gastrin receptors (CCK2R), overexpressed in most endocrine tumors, caused the death of cancer cells upon AMF exposure, making this approach an attractive therapeutic option $[4,8]$. Strikingly, in this study, as in others, no perceptible temperature rise in the cell medium occurred during AMF exposure [4 6]. Thus, MIIH differs from standard magnetic hyperthermia whereby tumor eradication is achieved with large doses of MINPs which cause a temperature elevation of the whole tumor [9]. However, it cannot be excluded that MILH also contributes to cell death during standard magnetic hyper thermia experiments since small amounts of MNP injected intra tumourously could be internalized by cancer cells. In MIIH, it is expected that MNPs, even of low heating power (Specific Absorption Rate), generate a local temperature rise causing LMP $[46,10]$. However, this appealing hypothesis has never

\footnotetext{
- Corresponding author at: INSERM ERL1226, 1 Avernue du Professeur Jean Poulhes, P-31432 Toubuse, France.

$E$-mall address: veronique.gigoux@inserm.fr (V. Gigaux).
} 
been directly proven experimentally. Moreover, the precise mechan isms leading to cell death by MILH remains largely unknown. Insight into these mechanisms is essential to optimize this approach in a therapeutic perspective.

To date, molecular mechanisms of lysosomal cell death of epithelial cells were mainly elucidated using lysosomotropic agents or death li gands which do not exclusively target lysosomes of cancer cells [11 13]. Lysosomal cell death through apoptosis was demonstrated to involve the release of lysosomal hydrolases into the cytosol, especially Cathepsin D and Cathepsin B (CathB) which digest apoptosis regulated proteins, leading to mitochondrial outer membrane permeabilization (MOMP) and apoptotic caspases activation [3,14].

The aim of this study was to elucidate the cellular and molecular mechanisms involved in cancer cell death induced by MILH. Here, we report that, under an AMF, lysosome accumulated MNPs increase the temperature very locally and enhance reactive oxygen species (ROS) production through the Fenton reaction within lysosomes. This causes lipid peroxidation of lysosome membrane, LMP and subsequent cell death by a non conventional mechanism which is dependent on Caspase 1 and CathB but independent of apoptotic Caspase 3. These major advances in the understanding of the cell death mechanism oc curring during MILH will facilitate optimization of the strategy in a therapeutic perspective.

\section{Material and methods}

\subsection{Nanoparticles functionalization}

The synthesis method and characterization of the magnetic nano platform used in the present article have been previously described [4]. The nanoplatform (Gastrin MNP) is composed of commercial iron oxide magnetic nanoparticles (MNPs) coated with PEG Amine (Gecco Dots, Sweden) and decorated with 100 molecules of a synthetic replicate of gastrin (Covalab) and 20 molecules of the fluorescent label NHS DY647 PEG1 (Dyomics GmbH, Jena, Germany). The size of the mag netic core determined by transmission electron microscopy was $8.7 \pm 1.6 \mathrm{~nm}$. The specific absorption rate of these MNPs is $13 \mathrm{~W} / \mathrm{g} \mathrm{Fe}$ at $275 \mathrm{kHz}$ and $40 \mathrm{mT}$. $N$ acetyl cystein (NAC), Desferroxamine (DFO), Bafilomycine A (BafA1), Artesunate (ART) and $\mathrm{FeCl}_{3}$ were purchased from Sigma Aldrich. CA $074 \mathrm{Me}$ and Caspase 3 inhibitors were from ApexBio. Caspase 1 inhibitor was from Santa Cruz Biotechnologies.

\subsection{Cell lines}

The glucagon producing Hamster tumoral cell line INR1G9 stably expressing CCK2R (INR1G9 CCK2R) obtained as previously described [15] and the Thp1 human macrophage/monocyte cell line were cul tured in RPMI1640 medium containing 10\% fetal bovine serum (FBS) and $100 \mathrm{IU} / \mathrm{ml}$ penicillin/streptomycin (Life technologies). The HEK293 cells (Flp In system, Invitrogen) stably expressing the CCK2R, named HEK CCK2R, and the clone B13 of AR4 2J cells (kindly provided by Pr Timo Otonkoski, University of Helsinki, Finland, with the per mission of Dr. Itaru Kojima, Gunma University, Maebashi, Japan) were cultured in DMEM medium containing 10\% fetal bovine serum (FBS) and $100 \mathrm{IU} / \mathrm{ml}$ penicillin/streptomycin (Life technologies). The AGS gastric adenocarcinoma cell line was permanently transfected with CCK2R (AGS CCK2R) driven by the EF1 $\alpha$ promoter under puromycin selection and grown in DMEM/F 12 medium supplemented with $10 \%$ FBS and $100 \mathrm{IU} / \mathrm{ml}$ penicillin/streptomycin [16]. The cells were grown in a humidified atmosphere at $95 \%$ air and $5 \% \mathrm{CO}_{2}$ at $37{ }^{\circ} \mathrm{C}$.

\subsection{Cell treatment by alternating magnetic field}

Cell treatment by alternating magnetic field (AMF) was performed as follows. Cells were seeded into 4 compartment Cellview dishes (Greiner Bio One) at a density of 25 to $50 \times 10^{3} \mathrm{cells} / \mathrm{cm}^{2}$, grown overnight and incubated with Gastrin MNPs (16 $\mu \mathrm{g} \mathrm{Fe} / \mathrm{ml})$ for $24 \mathrm{~h}$ at $37^{\circ} \mathrm{C}$ in medium buffered with $10 \mathrm{mM}$ HEPES buffer $\mathrm{pH} 7.4$ containing $0.5 \% \mathrm{FBS}$ and $100 \mathrm{IU} / \mathrm{ml}$ penicillin streptomycin to allow Gastrin MNPs internalization and accumulation in lysosomes. Incubation medium was withdrawn and cells were rinsed twice with incubation medium and then incubated with $5 \mathrm{mM}$ NAC, $1 \mathrm{mM}$ DFO, $1 \mathrm{nM}$ BafA1, $20 \mu \mathrm{M}$ ART, $10 \mu \mathrm{M}$ CA $074 \mathrm{Me}, 2.5 \mu \mathrm{M}$ Caspase 1 inhibitor or $10 \mu \mathrm{M}$ Caspase 3 in hibitor for $1 \mathrm{~h}$ or $120 \mu \mathrm{M} \mathrm{FeCl}_{3}$ for $4 \mathrm{~h}$ and exposed to AMF $(275 \mathrm{kHz}$, $40 \mathrm{mT}$ ) for $2 \mathrm{~h}$ using a commercial magnetic inductor (Fives Celes, Lautenbach, France) as previously described [4]. The temperature of the Cellview dish was maintained at $37.0 \pm 0.2{ }^{\circ} \mathrm{C}$ and controlled using a thermal probe (Reflex, Neoptix, Canada) placed in the incuba tion medium of the cells. At the end of the experiments, cells were placed in a humidified atmosphere at $5 \% \mathrm{CO}_{2}$ and $37{ }^{\circ} \mathrm{C}$. Different biological effects were analyzed following AMF exposure and sum marized in Supplementary Table 1.

\subsection{Determination of cell death}

The effects of AMF treatment were investigated as follows: first, cell survival was determined $24 \mathrm{~h}$ post AMF treatment using a MTT viability assay. Secondly, dead cells labeled with AnnexinV iFluor488 and pro pidium iodide (excitation: 488 and $540 \mathrm{~nm}$ respectively, AAT Bioquest) were counted $4 \mathrm{~h}$ after the end of AMF exposure as described before [4]. To analyze cell death in INR1G9 CCK2R overexpressing GFP CathB or Casp1 fusion protein, INR1G9 CCK2R cells were seeded at a density of $25 \times 10^{3}$ cells $/ \mathrm{cm}^{2}$ cells onto $35 \mathrm{~mm}$ dishes and transfected with $3 \mu \mathrm{g}$ of pCathB eGFP, pCathB C29A eGFP (given by Klaudia Brix, Jacobs Uni versity Bremen, Germany) or pMSCV2.2 IRES GFP Caspase 1 C284A (given by Dr. Petr Broz, University of Basel, Switzerland) using Lipo fectamine 2000 reagent (Life technologies). $4 \mathrm{~h}$ post transfection, cells were seeded onto 4 compartment Cellview dishes (Greiner Bio One) at a density of $25 \times 10^{3}$ cells $/ \mathrm{cm}^{2}$, grown overnight and incubated with Gastrin MNPs ( $16 \mu \mathrm{g} \mathrm{Fe} / \mathrm{ml}$ ) for $24 \mathrm{~h}$ at $37{ }^{\circ} \mathrm{C}$ in medium buffered with $10 \mathrm{mM}$ HEPES buffer pH 7.4 containing $0.5 \%$ FBS and $100 \mathrm{IU} / \mathrm{ml}$ pe nicillin streptomycin. Cells were rinsed twice with incubation medium, exposed to AMF for $2 \mathrm{~h}$, labeled with AnnexinV iFluor555 (excitation: $540 \mathrm{~nm}$, AAT Bioquest) $4 \mathrm{~h}$ after the end of AMF exposure and counted. Counting of labeled cells was carried out by analyzing confocal mi croscopy images (LSM510 confocal microscope, Zeiss) representing populations of 20003000 cells/experiment using ImageJ software.

\subsection{Analysis of ROS production}

INR1G9 CCK2R cells were seeded $24 \mathrm{~h}$ before the experiments onto 4 compartment Cellview dishes (Greiner Bio One) at a density of 25 to $50 \times 10^{3}$ cells $/ \mathrm{cm}^{2}$ and incubated with Gastrin MNPs $(16 \mu \mathrm{g} \mathrm{Fe} / \mathrm{ml})$ for $24 \mathrm{~h}$. Cells were rinsed twice with incubation medium and incubated with $5 \mathrm{mM}$ NAC, $1 \mathrm{mM}$ DFO, $1 \mathrm{nM}$ BafA1, $20 \mu \mathrm{M}$ ART for $1 \mathrm{~h}$ or $120 \mu \mathrm{M}$ $\mathrm{FeCl} 3$ for $4 \mathrm{~h}$. For total ROS production analysis, cells were exposed to AMF for $2 \mathrm{~h}$, rinsed with incubation medium, incubated with CellROX Green reagent (Molecular probes, Excitation wavelegnth: $488 \mathrm{~nm}$ ), immediately after AMF exposure, in incubation medium according to manufacturer's instructions and quantification of ROS production was performed by analyzing the intensity of CellROX Green reagent labeling of confocal microscopy images (LSM780 confocal microscope, Zeiss) using Image J software. 20003000 cells/experiments were analyzed in at least 4 independent experiments. For initial ROS production analysis, cells having or not internalized Gastrin MNPs were incubated in the presence or absence of $1 \mathrm{mM}$ DFO, $1 \mathrm{nM}$ BafA1, $20 \mu \mathrm{M}$ ART or $120 \mu \mathrm{M}$ $\mathrm{FeCl} 3$ and then with CellROX Green reagent (Molecular probes, Excitation: $488 \mathrm{~nm}$ ) in incubation medium according to manufacturer's instructions, exposed to AMF for $30 \mathrm{~min}$, rinsed with incubation medium and ROS production was analyzed using confocal microscopy (LSM780 confocal microscope, Zeiss) immediately after AMF exposure. Initial ROS production was quantified by fluorescence intensity ratio of 
a
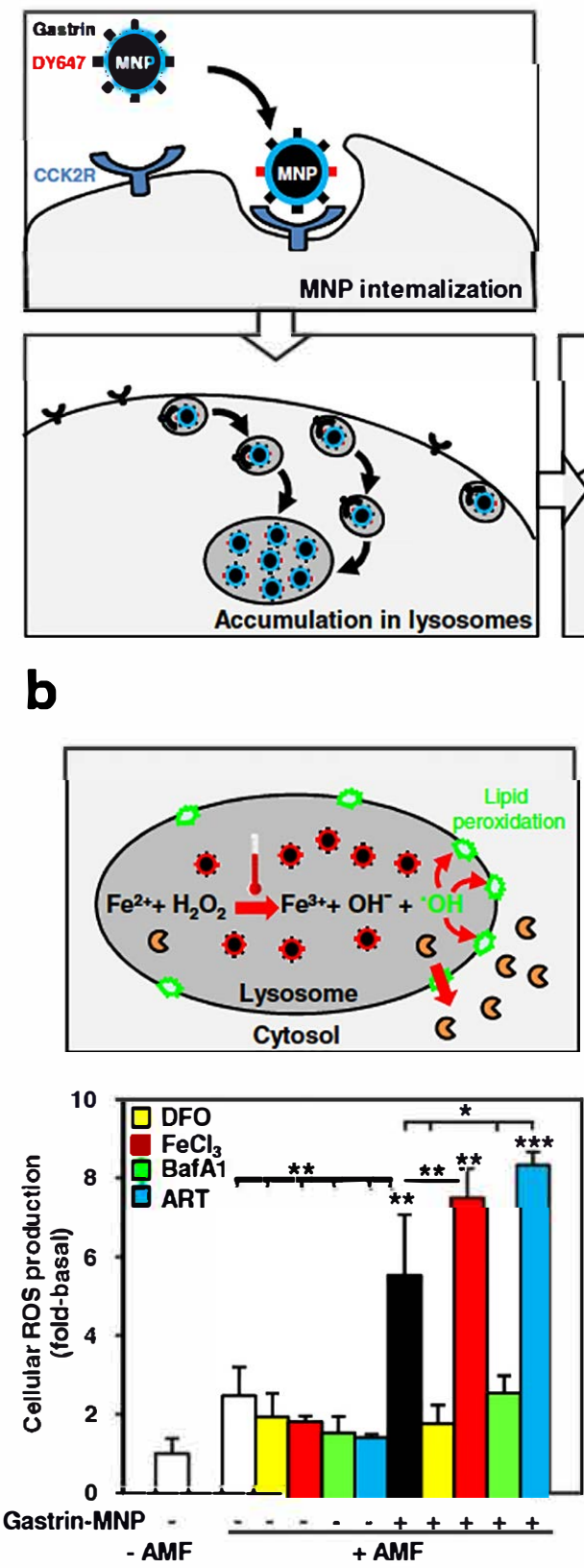

d

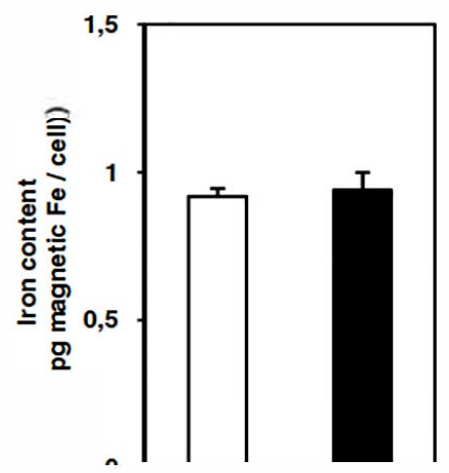

High frequency alternating magnetic field

(275 kHz, 40 mT)

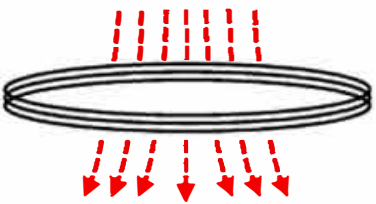

AMF $\cdots++$
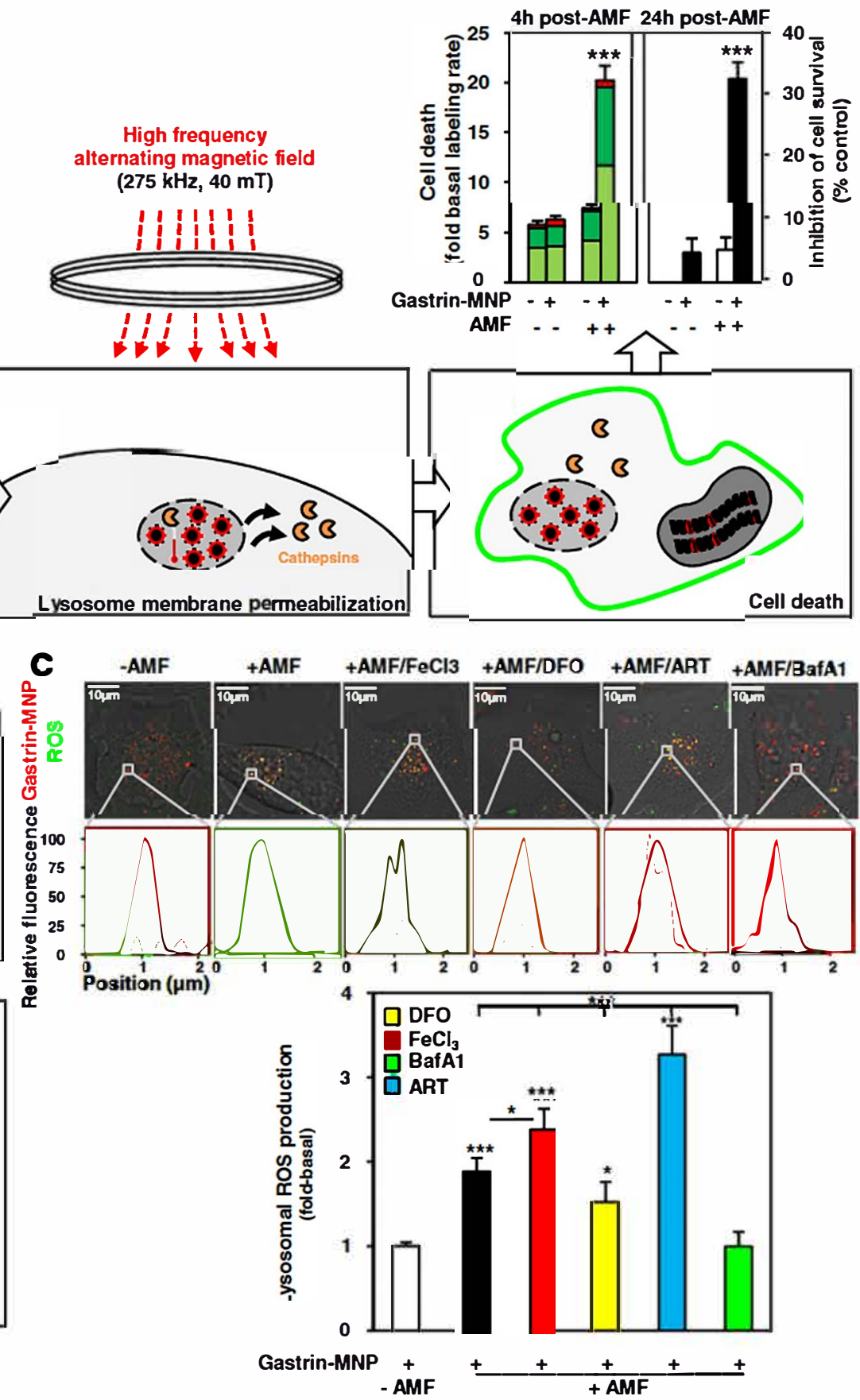

e

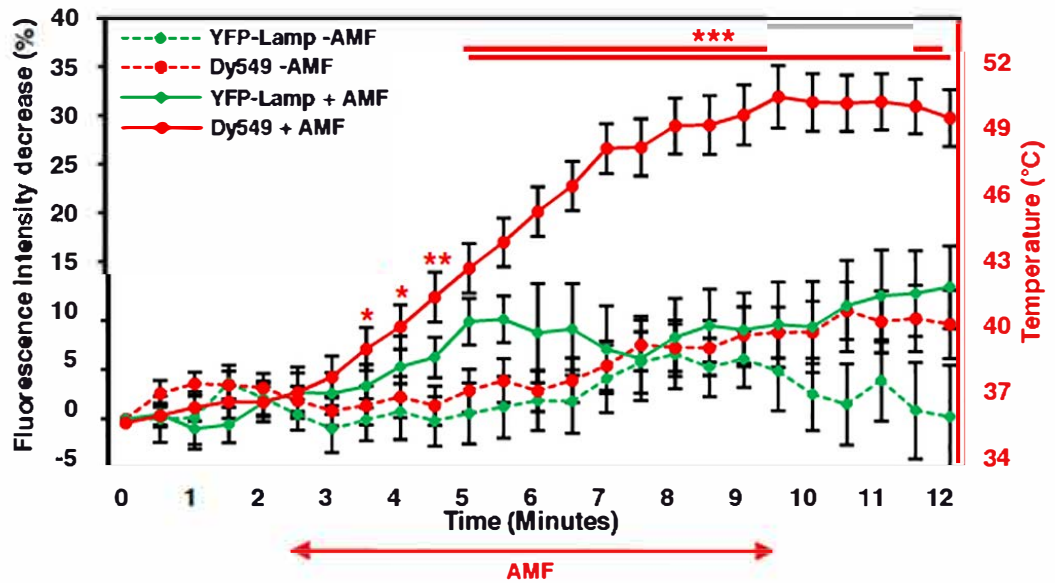

(coption on next page) 
Fig. 1. Magnetic Intra-Lysosomal Hyperthermia (MILH) induces ROS generation.

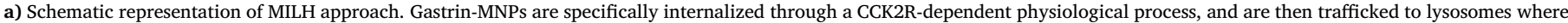

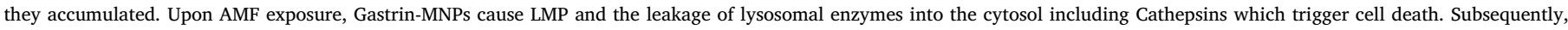

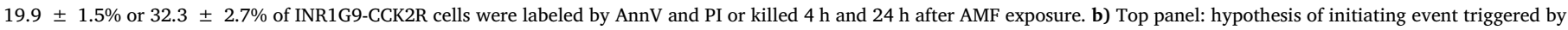

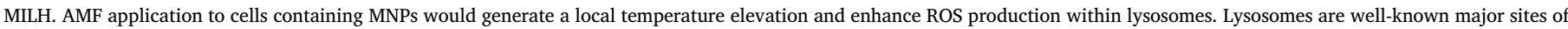

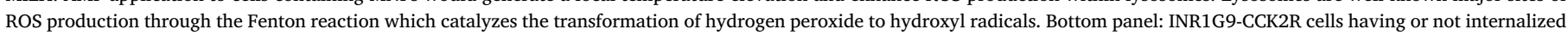

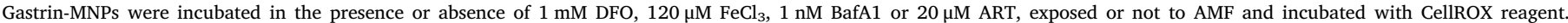

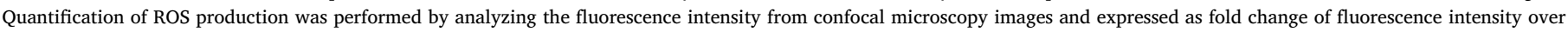

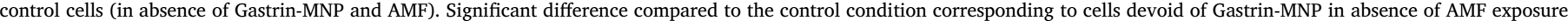

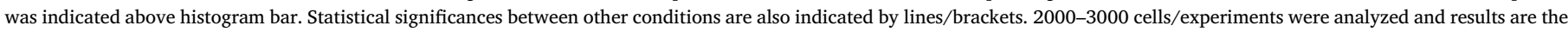

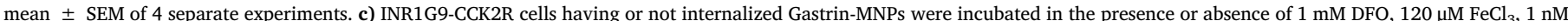

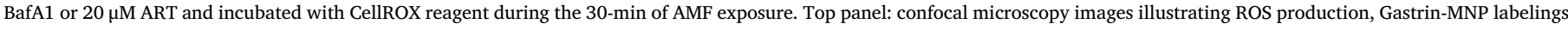

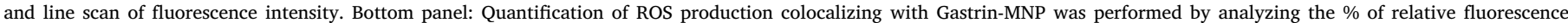

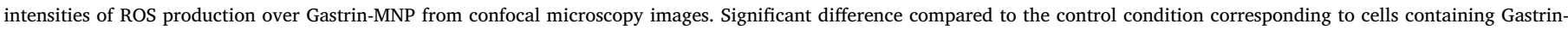

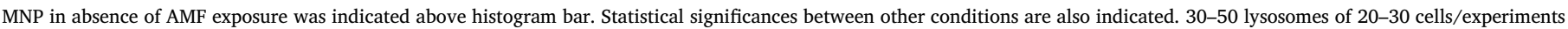

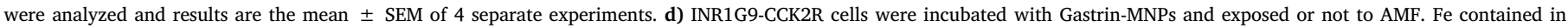

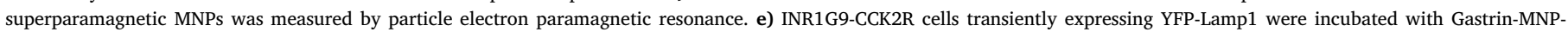

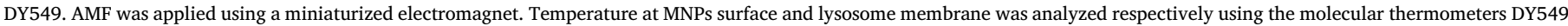

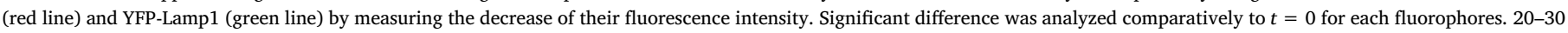

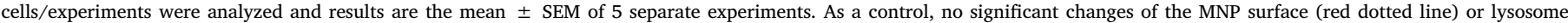

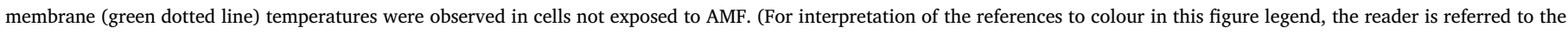
web version of this article.)

CellROX Green reagent to Gastrin MNP labeling of confocal microscopy images (LSM780 confocal microscope, Zeiss) using Image $\mathrm{J}$ software. 2030 cells/experiment were analyzed from at least 4 independent experiments.

\subsection{Local heat quantification using molecular thermometers}

INR1G9 CCK2R cells were seeded at a density of $25 \times 10^{3}$ cells $/ \mathrm{cm}^{2}$ onto $35 \mathrm{~mm}$ dishes and transfected with $0.1 \mu \mathrm{g}$ of YFP Lamp1 (Addgene, plasmid \#1816) and $2.9 \mu \mathrm{g}$ of pcDNA3 using Lipofectamine 2000 reagent (Life technologies). $24 \mathrm{~h}$ post transfection, cells were in cubated with Gastrin MNP DY549 (16 $\mu \mathrm{g} \mathrm{Fe} / \mathrm{ml})$ for $24 \mathrm{~h}$, included in $0.5 \%$ agarose gel. For these experiments, the AMF was produced by a miniaturized home made electromagnet placed in a CELLView dish and covered with RPMI containing $0.5 \%$ FBS, as previously described [17]. This permits to follow in real time the evolution of the fluorescence of the MNPs under the application of AMF and thus to have an access to the local temperature. For these experiments, different positions were marked inside and outside the gap. Cells were exposed to the AMF $(53 \mathrm{mT}, 300 \mathrm{kHz})$. Before and during AMF application, fluorescence intensities of DY549 (excitation: $540 \mathrm{~nm}$ ) and YFP Lamp1 (excitation: $510 \mathrm{~nm}$ ) were measured from confocal microscopy images LSM780 confocal microscope, Zeiss) using ImageJ software. 2030 cells/ex periment were analyzed from 4 independent experiments.

\subsection{CathB leakage from lysosome}

INR1G9 CCK2R cells were seeded at a density of $25 \times 10^{3}$ cells $/ \mathrm{cm}^{2}$ onto $35 \mathrm{~mm}$ dishes and transfected with $0.1 \mu \mathrm{g}$ of RFP Lamp1 (Addgene, plasmid\#1816), pCathB eGFP (given by Klaudia Brix, Jacobs University Bremen, Germany) and $2.9 \mu \mathrm{g}$ of pcDNA3 using Lipofectamine 2000 reagent (Life technologies). $4 \mathrm{~h}$ post transfection, cells were seeded onto 4 compartment Cellview dishes (Greiner Bio One) at a density of $25 \times 10^{3}$ cells $/ \mathrm{cm}^{2}$, grown overnight and in cubated with Gastrin MNPs $(16 \mu \mathrm{g} \mathrm{Fe} / \mathrm{ml})$ for $24 \mathrm{~h}$, rinsed twice with incubation medium and exposed to AMF for $2 \mathrm{~h}$. CathB leakage from lysosome was analyzed by measuring the colocalization between the GFP CathB and RFP Lamp1 proteins and the fluorescence intensity ratio of GFP CathB to RFP Lamp1 labelings (excitation: 488 and $540 \mathrm{~nm}$ re spectively) of confocal microscopy images (LSM780 confocal micro scope, Zeiss, ImageJ software) immediately after AMF exposure. 2030 cells/experiment were analyzed from 4 independent experiments.

For real time analysis of CathB leakage, INR1G9 CCK2R cells were seeded at a density of $25 \times 10^{3}$ cells $/ \mathrm{cm}^{2}$ onto $35 \mathrm{~mm}$ dishes and transfected with $0.1 \mu \mathrm{g}$ of pCathB eGFP (given by Klaudia Brix, Jacobs
University Bremen, Germany), $0.1 \mu \mathrm{g}$ RFP Lamp1 (Addgene, plasmid $\# 1817$ ) and $2.8 \mu \mathrm{g}$ of pcDNA3 using Lipofectamine 2000 reagent (Life technologies). $24 \mathrm{~h}$ post transfection, cells were incubated with Gastrin MNPs $(16 \mu \mathrm{g} \mathrm{Fe} / \mathrm{ml})$ for $24 \mathrm{~h}$. INR1G9 CCK2R cells expressing or not GFP CathB and having or not internalized Gastrin MNP were included in $0.5 \%$ agarose gel, poured into the electromagnet placed in a CELLView dish and covered with RPMI containing 0.5\% FBS, as pre viously described [17]. Different positions were marked inside and outside the gap. Cells were exposed to the AMF ( $53 \mathrm{mT}, 300 \mathrm{kHz}$ ) for $60 \mathrm{~min}$. Before and during AMF application, CathB leakage from lyso some was analyzed by measuring the colocalization between the GFP CathB and RFP Lamp1 proteins labeling from confocal microscopy images of the marked positions by measuring the $\%$ of green pixels (GFP CathB) colocalized with red pixels (RFP Lamp1) (ImageJ soft ware). 2030 cells/experiment were analyzed from 4 independent ex periments.

\subsection{Analysis of Caspase 1 and 3 activation}

Cells were seeded $24 \mathrm{~h}$ before the experiments onto 4 compartments Cellview dishes (Greiner Bio One) at a density of 25 to $50 \times 10^{3}$ cells/ $\mathrm{cm}^{2}$ and incubated with Gastrin MNPs $(16 \mu \mathrm{g} \mathrm{Fe} / \mathrm{ml})$ for $24 \mathrm{~h}$ and ex posed to AMF for $2 \mathrm{~h}$. Immediately, 3 or $17 \mathrm{~h}$ after AMF exposure, cells were incubated with Fluorochrome Labeled Inhibitors of Caspase 1 (FLICA, FAM YVAD FMK, excitation: $488 \mathrm{~nm}$ ) or Caspase 3 (FLICA, FAM DEVD FMK, excitation: $488 \mathrm{~nm}$ ) reagent (Immunochemistry technologies) for $1 \mathrm{~h}$ according to manufacturer's instructions. As a positive control for Caspase 3 activation, INR1G9 CCK2R cells were incubated with $1 \mu \mathrm{M}$ staurosporine for $4 \mathrm{~h}$. In some experiments, cells were pretreated with $2.5 \mu \mathrm{M}$ Caspase 1 inhibitor, $10 \mu \mathrm{M}$ Caspase 3 in hibitor or $10 \mu \mathrm{M} \mathrm{CA} 074 \mathrm{Me}$ CathB inhibitor for $1 \mathrm{~h}$. Inhibitors were washed from the cells before adding FLICA. Next, cells were washed and analyzed by confocal micrsocopy (LSM510 confocal microscope, Zeiss). After Caspase 1 staining, cells were labeled with AnnexinV iFluor555 according to manufacturer's instruction (AAT Bioquest). Counting of labeled cells was carried out by analyzing confocal mi croscopy images representing populations of 20003000 cells/experi ment using ImageJ software.

\subsection{Statistical analysis}

Results are expressed as the mean \pm SEM of at least three in dependent experiments. Statistical analysis was performed using ANOVA test. Differences were considered significant when $\mathrm{p}<0.05$. 
2.10. Lipid peroxidation, mitochondrial membrane potential assay, DNA fragmentation, Il $1 \beta$ secretion, Western blotting, analysis of lysosomal acidity

See Supplementary information and Supplementary Table 1.

\section{Results}

\subsection{Magnetic Intra Lysosomal Hyperthermia (MILH) enhances ROS production through the Fenton reaction within lysosomes}

Over expression of hormone receptors is a hallmark of neuroendo crine tumors which thus represent a perfect model for the experi mentation of tumor cell targeting with ligand grafted MNPs. We pre viously showed that Gastrin grafted iron oxide MNPs (termed Gastrin MNP) are internalized specifically by the pancreatic endocrine tumoral cells INR1G9 overexpressing the CCK2R (INR1G9 CCK2R cells) through a CCK2R dependent physiological process, and are then trafficked to lysosomes where they accumulated (Fig. 1a). Of note, Gastrin MNPs exist under nano objects containing nanoparticles and serum adsorbed proteins whose distribution slightly increased from a size around 37 to $50 \mathrm{~nm}$ after $24 \mathrm{~h}$ of incubation in cell culture medium (data not shown). Upon AMF exposure, Gastrin MNPs killed $32.3 \pm 2.7 \%$ of INR1G9 CCK2R cells by a phenomenon that we termed "Magnetic Intra Lyso somal Hyperthermia" (MILH) [4] (Fig. 1a). $4 \mathrm{~h}$ after MILH treatment, the rate of cell damage reached $19.9 \pm 1.5 \%$ (i.e. $3.5 \pm 0.3$ fold basal) as indicated by AnnexinV and propidium iodide (AnnV/PI) la belings (Fig. 1a). Both AnnV and PI labelings, which constitute early features of MILH cell death, were thus used throughout our study to appreciate cell death.

So far, our current knowledge on the mechanism of cancer cell death caused by MILH treatment is still elusive, although we and others identified cellular ROS production and lysosome leakage as biological events accompanying cell death $[4,5,17]$. To gain insight into cell death mechanisms, we hypothesized that AMF application to cells containing MNPs would generate a local temperature elevation and, inasmuch as MNPs are concentrated into lysosomes, heating of lysosome content would trigger a death signaling cascade initiated by the enhancement of ROS production within lysosomes. Indeed, in addition to being a major digestive compartment, lysosomes are well known major sites of ROS production through the Fenton reaction $\left(\mathrm{Fe}^{2+}+\mathrm{H}_{2} \mathrm{O}_{2} \rightarrow\right.$ $\mathrm{Fe}^{3+}+\mathrm{OH}+\mathrm{OH}^{-}$) which catalyzes the transformation of hydrogen peroxide to hydroxyl radicals. This reaction is dependent on low mo lecular weight iron derived from degraded iron containing proteins, lysosomal lumen acidity and temperature [18 20]. It is also known that high levels of ROS cause lysosome membrane permeabilization (LMP) whereby lysosomal cathepsins, as well as other hydrolytic enzymes, are released from the lysosomal lumen to the cytosol and trigger cell death (Fig. 1a b) [21]. In INR1G9 CCK2R cells, MILH increased ROS levels by $5.7 \pm 1.5$ fold over the basal value (Fig. 1b, S1a). Such effect is po tentiated by the addition of $\mathrm{FeCl}_{3}$ which increased ROS levels to $7.5 \pm 0.7$ fold. In contrast, intralysosomal chelation of iron by Des ferrioxamine (DFO) [22] prevented MILH increased cellular ROS pro duction which returned nearly to the basal value $(2.0 \pm 0.5$ fold over basal). Also, the inhibition of the vacuolar $\mathrm{H}^{+}$ATPase pump by Bafi lomicyne A (BafA1) treatment which caused intralysosomal $\mathrm{pH}$ rise (Fig. S1b) decreased MILH induced cellular ROS level to $2.7 \pm 0.4$ fold over basal value (Fig. 1b, S1a). Conversely, treatment of cells by Artesunate (ART), an activator of vacuolar $\mathrm{H}^{+}$ATPase pump de creasing intralysosomal pH (Fig.S1b) [20], increased MILH enhanced cellular ROS production from $5.7 \pm 1.5$ to $8.3 \pm 0.3$ fold over basal value (Fig. 1b, S1a).

We previously showed that ROS production was significantly de tectable after $30 \mathrm{~min}$ of AMF exposure [17]. To precisely identify subcellular site(s) of ROS which are initially produced in MILH condi tion, a series of experiments combining confocal microscopy imaging and pharmacological agents were carried out. Firstly, analysis of con focal microscopy images indicated that fluorescent ROS sensor co lo calized with Gastrin MNPs in lysosomes after $30 \mathrm{~min}$ of AMF exposure (Fig. 1c). Quantification of lysosomal ROS images showed that MILH enhanced ROS level by $2.0 \pm 0.2$ fold in the vicinity of Gastrin MNPs within lysosomes (\% of relative fluorescence Gastrin MNP/ROS: $48.5 \pm 3.9 \%$ vs $24.8 \pm 1.1 \%$ ). Moreover, addition of $\mathrm{FeCl}_{3}$ aug mented MILH induced lysosomal ROS production by $1.3 \pm 0.1$ fold (\% of relative fluorescence Gastrin MNP/ROS: $60.7 \pm 6.1 \% \quad v s$ $48.5 \pm 3.9 \%)$, wheareas DFO inhibited it $(37.8 \pm 5.8 \%)$. Variation of lysosomal $\mathrm{pH}$ also modified lysosmal ROS production. Indeed, while ART treatment increased MILH induced lysosomal ROS production by $1.7 \pm 0.1$ fold $(\%$ of relative fluorescence Gastrin MNP/ROS: $80.9 \pm 8.5 \%$ vs $48.5 \pm 3.9 \%)$, BafA1 inhibited it $(24.7 \pm 4.2 \%)$. Together, these results demonstrate that MILH initially generates ROS through the Fenton reaction within lysosomes where Gastrin MNPs are accumulated.

However, as the ROS production can occur in other subcellular sites, we also determined whether MILH also generates ROS by activating, for instance, the mitochondrial respiratory chain complex or NADPH oxi dases which are transmembrane proteins mostly present at the plasma membrane, in endosomes and in endoplasmic reticulum [23]. We found that rotenone, an inhibitor of the mitochondrial respiratory chain complex, did not modify cellular ROS generation by MILH, whereas diphenyleneiodonium (DPI), an inhibitor of NADPH oxidases, de creased it $(5.9 \pm 1.8$ and $3.8 \pm 1.3$ fold over basal value in the presence of rotenone or DPI, respectively versus $5.7 \pm 1.5$ fold) (Fig. S2). Hence, MILH initially triggers ROS production through the Fenton reaction within lysosomes and, likely secondary, through NADPH oxi dases. Of note, no significant variation in ROS level was observed be tween the different conditions in the absence of AMF exposure (Fig. S1a, S2).

We further investigated the mechanism whereby MILH enhanced the Fenton reaction in lysosomes. Firstly, we examined the possibility that Fe ions, participating in the Fenton reaction, could originate from MNPs dissolution in lysosomes during AMF exposure. Indeed, it has been reported that iron oxide MNPs, in the absence of AMF application, are degraded through a lysosomal acidic and enzymatic lysis in the endo lysosome compartment [24,25]. On the other hand, another study performed at neutral $\mathrm{pH}$, attributed ROS production to the catalytic reaction at the surface of MNPs rather than to being caused by dissolved iron from MNPs [26]. Using particle electron paramagnetic resonance (pEPR) to determine the quantity of iron contained in the cells under the form of MNPs, we found that internalized Gastrin MNPs were not degraded following AMF application $(0.94 \pm 0.06 v s 0.92 \pm 0.03 \mathrm{pg}$ magnetic Fe/cell) (Fig. 1d). However, we cannot exclude that iron could have been released from Gastrin MNPs during their $24 \mathrm{~h}$ traf ficking in the endo lysosome compartment prior to magnetic field ap plication. Consequently, these results indicate that MILH induced ROS production was the result of enhanced Fenton reaction catalysis using cellular lysosomal iron or possibly iron from MNPs, dissolved most likely before AMF application.

Secondly, we evaluated the temperature rise during MILH experi ments. So far, our experimental data indicate that the death of cancer cells in MILH occurs without any perceptible rise in the global tem perature of the medium. The hypothesis that local heating occurs at proximity of MNPs has been supported by several experimental reports [27], but direct data accounting for such a phenomenon in MILH were still lacking. In particular, no intracellular or intra lysosomal tem perature measurement under magnetic hyperthermia experiments has been reported so far in the literature. We therefore conducted such experiments, using fluorescent molecular thermometers and the pre viously described miniaturized high frequency electromagnet which enables confocal fluorescence imaging of cells during MILH experi ments [17]. Molecular thermometers were composed of the fluorescent moieties DY549 attached to MNPs via PolyEthyleneGlycol of $7 \mathrm{~nm}$ 
a
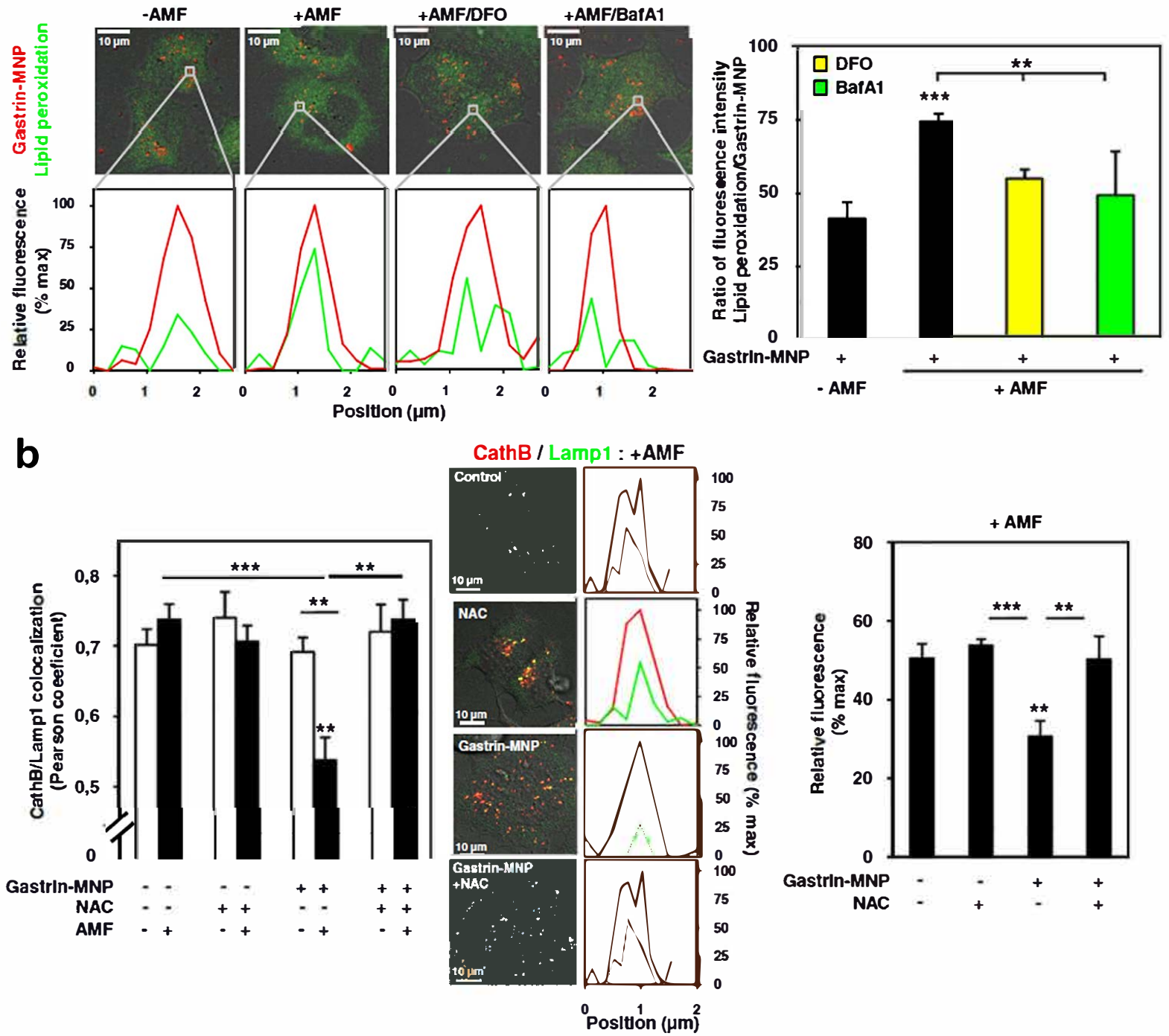

Gastrin-M
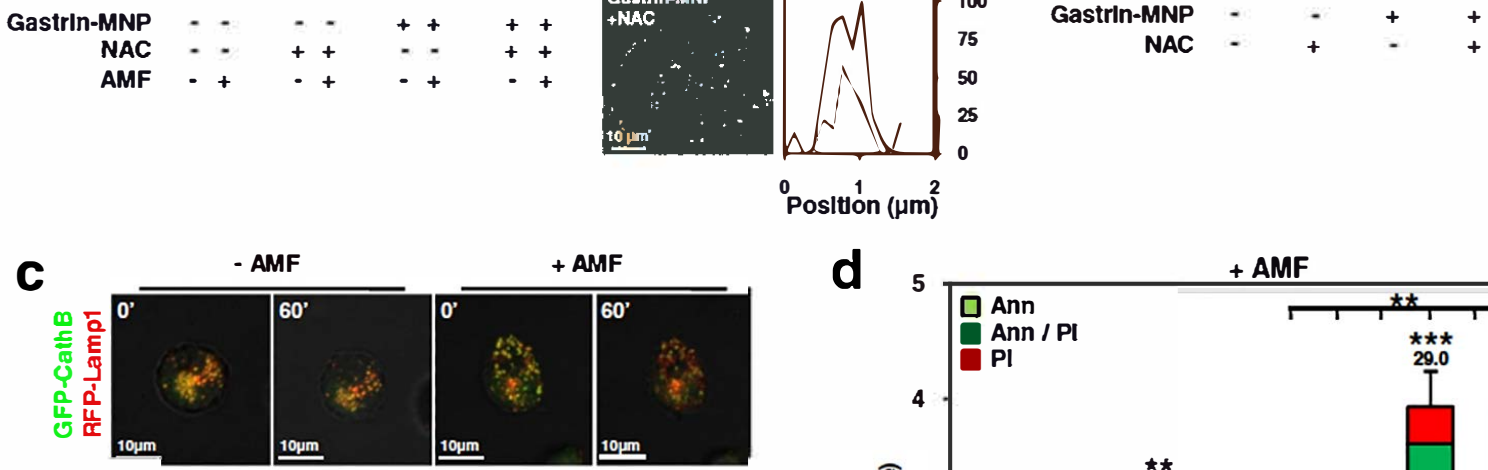

d 5
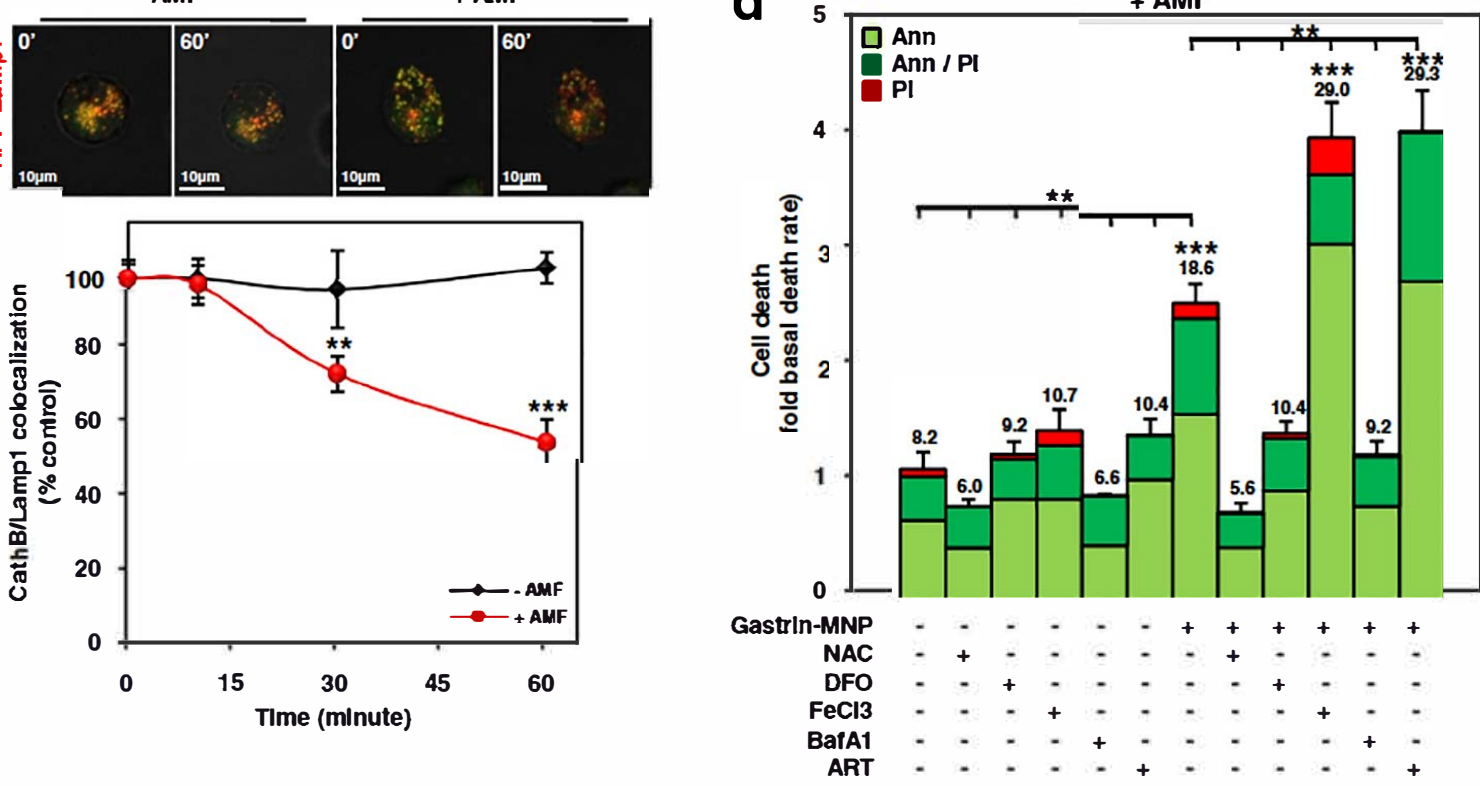

(caption on next page) 
Fig. 2. MILH-induced ROS generation causes lysosome lipid peroxydation, lysosome membrane permeabilization and cell death.

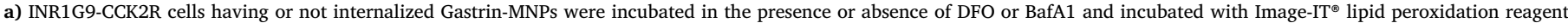

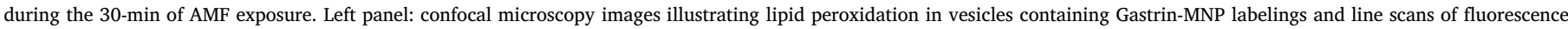

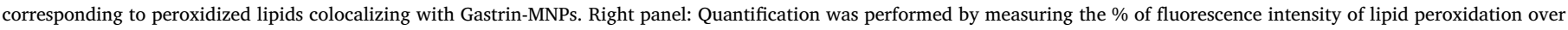

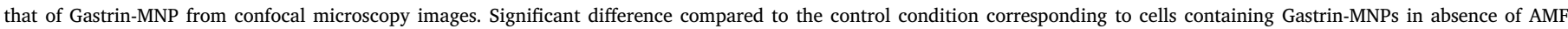

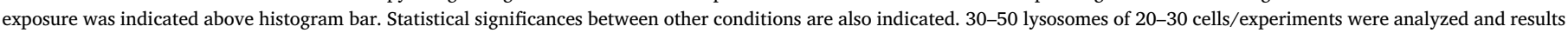

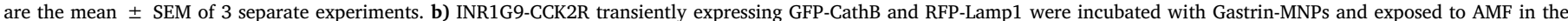

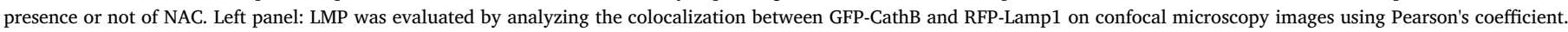

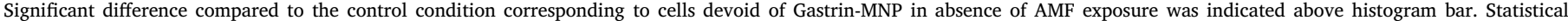

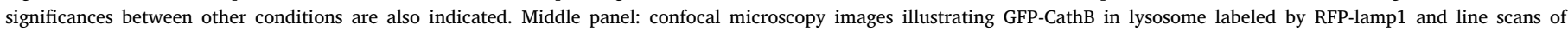

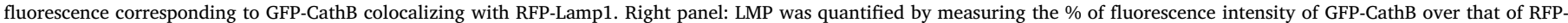

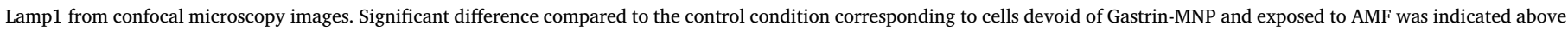

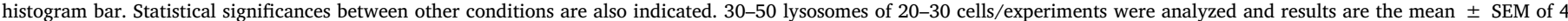

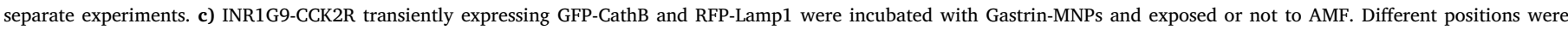

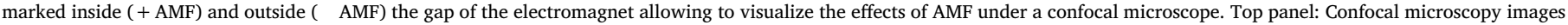

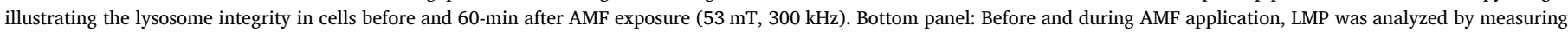

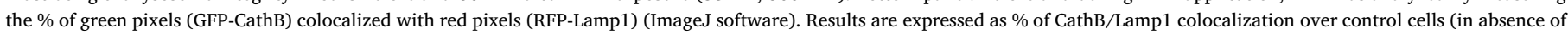

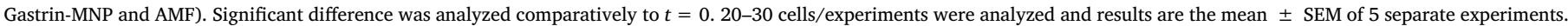

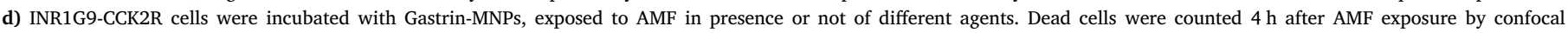

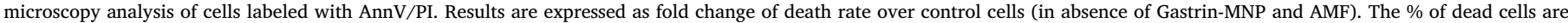

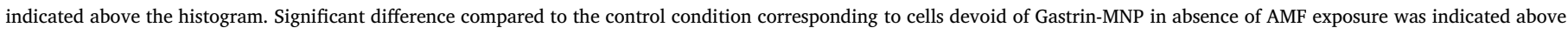

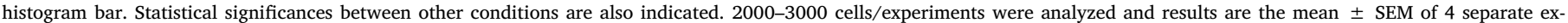
periments. (For interpretation of the references to colour in this figure legend, the reader is referred to the web version of this article.)

length or the Yellow Fluorescent Protein (YFP) linked to Lysosome Associated Membrane Protein 1 (Lamp1) [4]. Intensity of fluorescence emission of the two probes was previously shown to depend on tem perature [28]. This relationship was confirmed by the calibration curve showing linearity of fluorescence intensity decrease as a function of temperature increase (Fig. S3). Quantitative fluorescence imaging was then carried out on cells exposed to AMF for a limited duration $(<10$ min) and incubated with ROS scavenger NAC in order to preserve ly sosome integrity and avoid possible chemical quenching of the fluor escent molecular thermometers by ROS. As shown on Fig. 1e, fluores cence intensity of DY549 grafted to MNPs declined with the time of AMF exposure. According to the calibration curve (Fig. S3), the per centage of decrease of fluorescence intensity observed after $\sim 7 \mathrm{~min}$ of treatment corresponds to a temperature increase of $14.1 \pm 1.4^{\circ} \mathrm{C}$, indicating that the temperature actually reached $51{ }^{\circ} \mathrm{C}$ at $7 \mathrm{~nm}$ distance from the MNP core. However, fluorescence intensity of YFP Lamp1 did not significantly change during MILH experiments (Fig. 1e). These re sults strongly support that AMF exposure to MNPs that have been ac cumulated in lysosomes causes a significant temperature increase at the immediate vicinity of the MNPs since it is not detected at the outer surface of lysosomes.

\subsection{MILH enhanced ROS production within lysosomes causes lysosomal membrane permeabilization and cell death}

We further assessed the relationship between ROS generation within lysosomes and cell damage. ROS can destabilize and permeabilize ly sosome membranes through lipid and protein peroxidation [3]. We performed experiments combining confocal microscopy imaging and pharmacological agents to analyze whether MILH induces the perox idation of lysosomal lipids (Fig. 2a). Analysis of confocal microscopy images indicated that MILH enhanced the level of lipid peroxidation which was detectable from $30 \mathrm{~min}$ of AMF application, and co localized with Gastrin MNPs (\% of relative fluorescence: $74.4 \pm 2.7 \%$ vs $41.5 \pm 5.6 \%$ ). Moreover, intralysosomal chelation of iron by DFO or BafA1 treatment decreased MILH induced lysosomal lipid peroxidation $(54.4 \pm 3.1 \%$ and $48.7 \pm 15.1 \%)$. Together, these results demon strate that MILH induces lysosomal lipid peroxidation concomitantly with lysosomal ROS production.

Since MILH stimulates lysosomal ROS production and lipid perox ydation, it appeared likely that LMP subsequently occurs. Previously, we documented that, in MILH experiments, lysosomal integrity was affected as suggested by the decrease of lysosome labeling by LysoTracker. However, the criterium of LysoTracker labeling is insufficient to characterize LMP since it may account for leaking of low molecular weight components and not lysosomal enzymes which are key actors in lysosome functions. Herein, we determined whether ROS production in lysosomes truly triggered LMP. The decrease of CathB content in lysosomes (labeled with RFP Lamp1) was chosen to re present lysosomal enzyme leakage (Fig. 2b). In absence of AMF appli cation, INR1G9 CCK2R cells having internalized Gastrin MNPs pre sented a high level of GFP CathB/RFP Lamp1 colocalization which was reduced by the application of AMF (Pearson coefficient: $0.54 \pm 0.03 v \mathrm{~s}$ $0.69 \pm 0.02$ in presence $v s$ absence of AMF). The effect of MILH on GFP CathB/RFP Lamp1 colocalization was cancelled in the presence of the NAC scavenger (Pearson coefficient: $0.74 \pm 0.03$, Fig. 2b, S4). Moreover, quantification of fluorescence intensity showed that MILH decreased lysosomal CathB levels by $19.2 \pm 3.7 \%$ (\% of relative fluorescence: $30.7 \pm 3.9 \%$ vs $50.5 \pm 3.8 \%$ ), whereas addition of NAC prevented it $(50.3 \pm 5.8 \%)$. These results demonstrate that lysosomal leakage was entirely related to MILH enhanced ROS production.

We then determined whether the leakage of CathB from lysosomes constituted an early event in the signaling cascade leading to cell death. During MILH experiments performed using the miniaturized electro magnet [17], we evaluated in real time the decrease of the colocaliza tion of GFP CathB with RFP Lamp1, a protein resident of lysosome membrane (Fig. 2c). Before or after AMF exposure, INR1G9 CCK2R cells having internalized Gastrin MNPs presented a high level of GFP CathB/RFP Lamp1 colocalization (Pearson coefficient $>0.70$ ). How ever, the lysosomal CathB level decreased significantly by $25.4 \pm 4.7 \%$ and $43.9 \pm 6.3 \%$ after 30 and 60 min of MILH treat ment respectively, demonstrating that leakage of lysosome content is an early event occurring concomitantly with the generation of lysosomal ROS. Of note, RFP Lamp1 and GFP CathB fluorescence intensities, other LMP markers [29], decreased respectively by $20 \pm 2.4 \%$ and $16.5 \pm 6.6 \%$ from $30 \mathrm{~min}$ of AMF exposure (Fig. S7), strongly sug gesting that the changes in RFP Lamp1 and GFP CathB fluorescence represent respectively lysosomal rupture and CathB leakage from ly sosome into the cytosol and that both events occur early in the signaling cascade leading to cell death.

Finally, we wished to establish the relationship between ROS gen eration within lysosomes and cell death MILH experiments. We found that the addition of $\mathrm{FeCl}_{3}$ or ART, which enhance ROS production in the cell medium, augmented cell death induced by MILH $(4.0 \pm 0.3$ and $4.1 \pm 0.4$ fold over basal value respectively $v s 2.6 \pm 0.2$ fold in presence of Gastrin MNP alone, Fig. 2d, S5). In contrast, NAC, DFO and BafA1 treatments which trapped ROS or inhibited their formation, prevented MILH induced cell death $(0.8 \pm 0.1,1.4 \pm 0.1$ and 
a

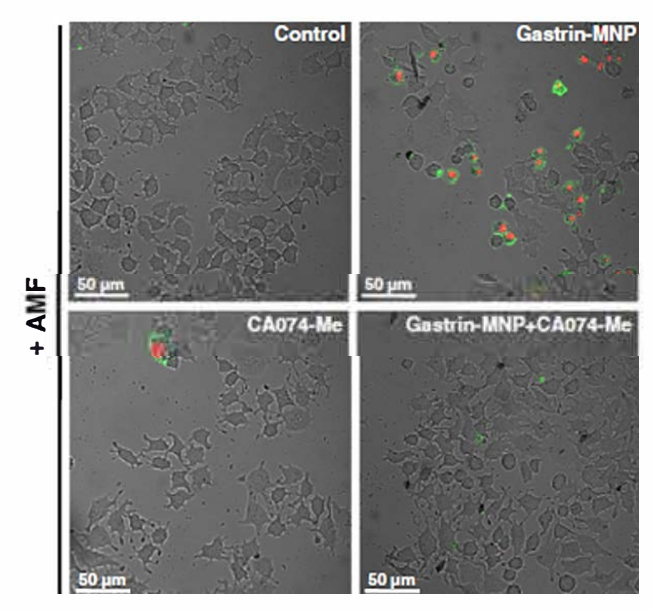

b

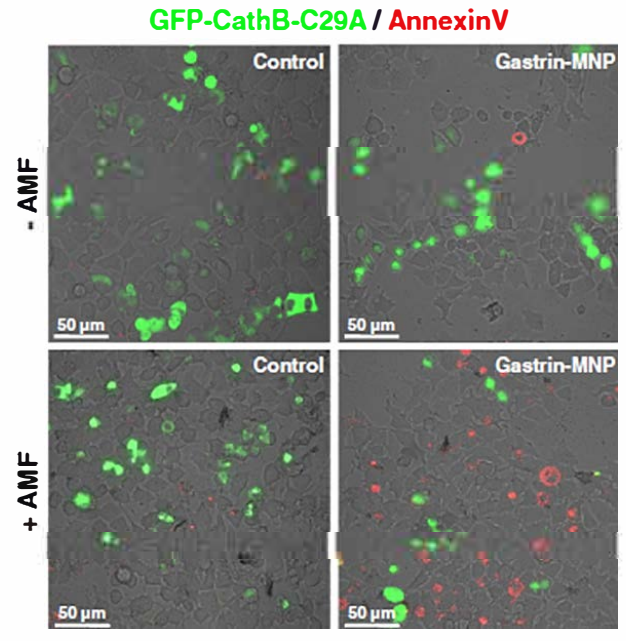

C

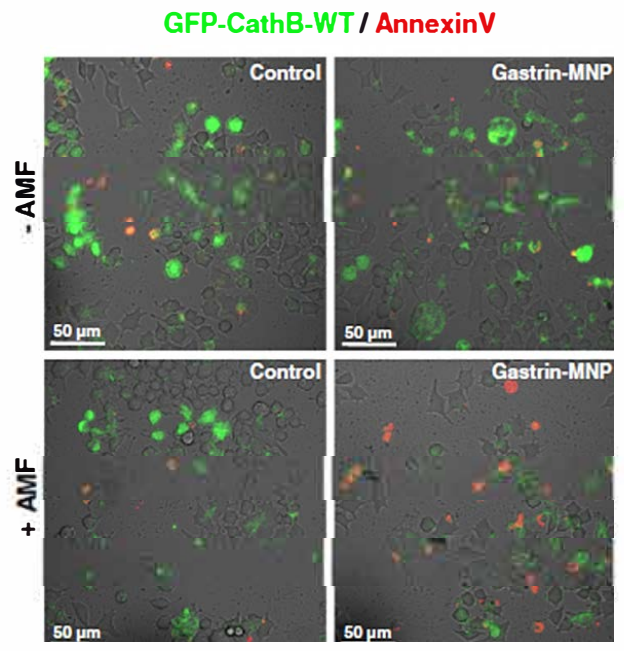

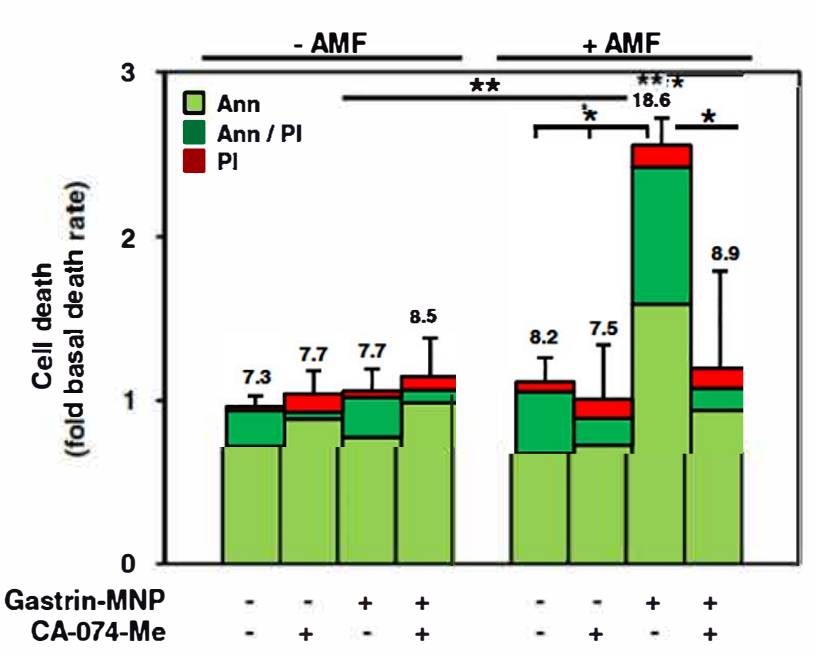
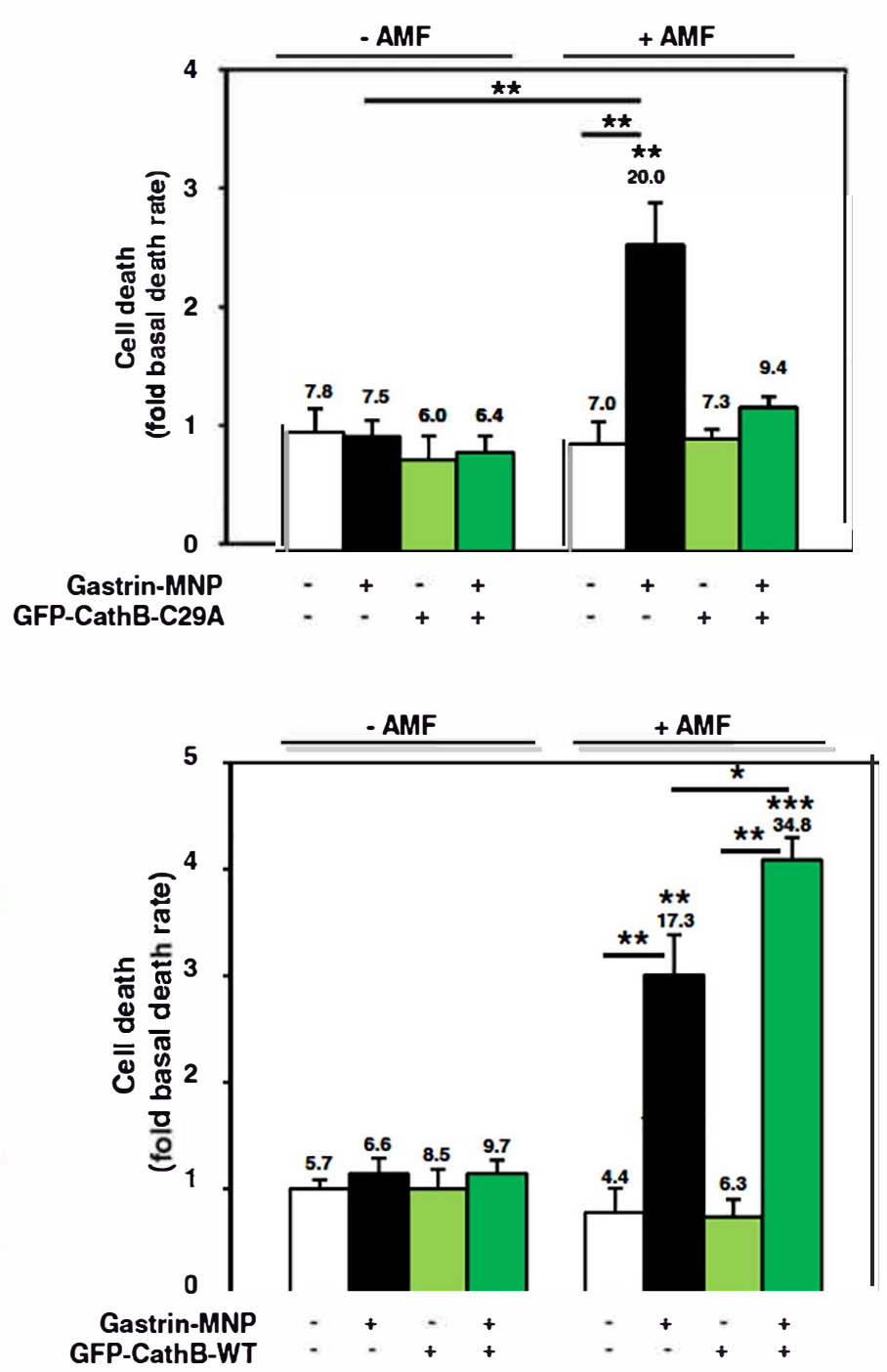

(caption on next page) 
Fig. 3. Cell death induced by MILH is dependent on CathB activity.

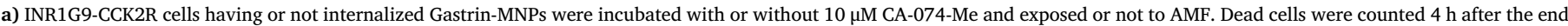

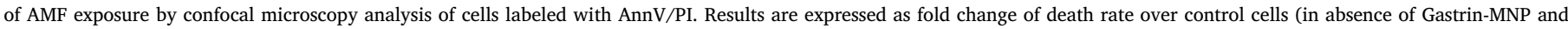

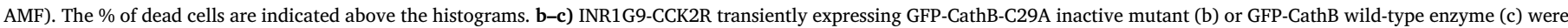

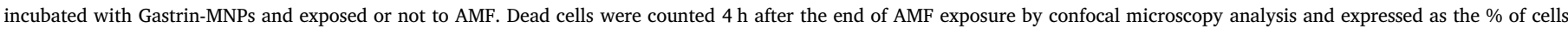

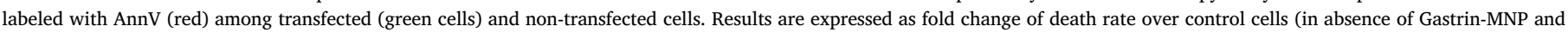

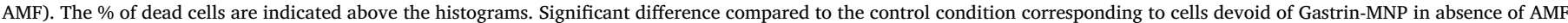

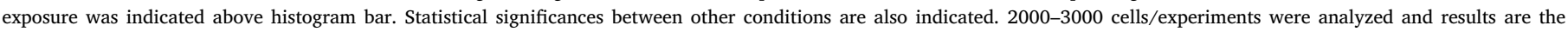
mean \pm SEM of at least 4 separate experiments. (For interpretation of the references to colour in this figure legend, the reader is referred to the web version of this article.)

$1.3 \pm 0.1$ fold over basal value respectively) (Fig. 2d, S4 S5). More over, MILH induced cell death was not inhibited by rotenone or DPI (Fig. S6), indicating that neither the mitochondria respiratory chain complex nor NADPH oxidases were involved in cell death, further supporting the idea that ROS generated by NADPH oxidases are sec ondary to lysosomal stress caused by MILH treatment. All together, these results demonstrate that lysosomal ROS production, which is enhanced by MILH through the Fenton reaction, is at the origin of cancer cell death.

\subsection{Cancer cell death induced by MILH is dependent on CathB activity}

In a previous study, we showed that MILH induced cell death de pends on lysosomal cysteine cathepsins which include cathepsins B, C, $\mathrm{H}, \mathrm{K}, \mathrm{L}, \mathrm{S}$ and $\mathrm{X}$ [4]. Herein, we performed experiments to more pre cisely identify the enzyme(s) involved. A likely candidate is CathB which is involved in lysosomal cell death, abundant in lysosomes, overexpressed in cancers and maintains its activity at neutral $\mathrm{pH}$ [30 32]. MILH experiments were performed in the presence of the se lective inhibitor of CathB CA $074 \mathrm{Me}$ [33] or by overexpressing the enzymatically inactive mutant GFP CathB C29A. As shown in Fig. 3a b, both the inhibitor CA $074 \mathrm{Me}$ and the inactive mutant GFP CathB C29A prevented MILH induced cell death $(1.2 \pm 0.1$ and $1.5 \pm 0.1$ fold over basal value vs $2.5 \pm 0.1$ fold). In contrast, overexpression of wild type CathB (GFP CathB WT) augmented the efficiency of MILH to era dicate cancer cells $(4.1 \pm 0.2$ vs $3.0 \pm 0.3$ fold over basal, Fig. $3 \mathrm{c})$ reaching $34.8 \%$ of dead cells comparatively to $17.3 \%$ of dead cells in the absence of CathB WT overexpression. These results indicate that cell death induced by MILH is dependent on CathB activity.

\subsection{MILH induces cell death through a Caspase 1 dependent but Caspase 3 independent mechanism}

So far, in most circumstances, partial LMP induce cell death through an apoptotic pathway, by triggering a cascade of regulated molecular events leading to activation of the effector apoptotic enzyme Caspase 3 $[3,14]$. We therefore investigated whether MILH also induces cell death through an apoptotic pathway. Surprisingly, the Caspase 3 inhibitor did not inhibit MILH induced cell death $(2.7 \pm 0.2 \%$ vs $2.8 \pm 0.2$ fold over basal) whereas it prevented cell death induced by staurosporine used as a reference agent to stimulate apoptosis (Fig. 4a). Moreover, Caspase 3 activation was not detected neither by confocal microscopy using a fluorescent substrate (Fig. 4b), nor by western blot as shown by the absence of Pro Caspase 3 cleavage (Fig. S8). We also showed that MILH did not modify mitochondrial outer membrane permeabilization (MOMP), which critically relies on apoptotic cell death, as demon strated with staurosporine treatment (Fig. $4 \mathrm{c}, \mathrm{S} 9$ ), $4 \mathrm{~h}$ or $24 \mathrm{~h}$ after AMF exposure [34]. Hence, cell death induced by MILH does not involve an apoptotic pathway.

In some non epithelial cells, especially in macrophages exposed to infectious agents, the release of lysosomal hydrolases such as CathB induced after LMP was shown to activate a non apoptotic cell death pathway involving Caspase 1 activation [35]. We therefore verified Caspase 1 expression in INR1G9 CCK2R cells (Fig. S10) and determined whether Caspase 1 was involved in MILH induced tumor cell death.
Incubation of INR1G9 CCK2R cells with Caspase 1 inhibitor prevented cell death induced by MILH $(1.6 \pm 0.2$ vs $2.8 \pm 0.2$ fold over basal, Fig. 4d). Likewise, overexpression of Caspase 1 C284A inactive mutant inhibited cell death $(1.5 \pm 0.2$ vs $3.0 \pm 0.2$ fold over basal, Fig. $4 \mathrm{e})$. It was also noticed that overexpression of Caspase $1 \mathrm{C} 284 \mathrm{~A}$ inactive mutant lowered basal rate of cell death (amount of dead cells: $1.2 \pm 0.4 \%$ vs $6.5 \pm 0.9 \%$ ). Moreover, MILH increased Caspase 1 activation $(3.5 \pm 0.4,9.0 \pm 1.3$ and $12.5 \pm 2.4$ fold over basal $1 \mathrm{~h}$, $4 \mathrm{~h}$ and $18 \mathrm{~h}$ after AMF exposure) and this activation was inhibited by CathB inhibitor CA $074 \mathrm{Me}$ (Fig. 4f, S11). It is also important to note that $84.5 \pm 2.3 \%$ of cells presenting an upregulated Caspase 1 activity were labeled with AnnexinV (Fig. 4g). Taken together, these results demonstrate that cell death induced by MILH does not involve an apoptotic pathway, but requires Caspase 1 and Cath B activities.

An important function of Caspase 1 consists to process the precursor of the inflammatory cytokines, interleukine $1 \beta$ (Il1 $\beta$ ) and interleukine 18 (Il 18) into their active forms [36]. Furthermore, activation of Caspase 1 in cells is a hallmark of pyroptosis, which is a form of regulated cell death, usually defined by several additional biochemical features such as independence of apoptotic caspases, Ann/PI positive labeling, DNA fragmentation [37]. The current study demonstrates that MILH induced cell death is dependent on Caspase 1 activation and featured by Ann/PI labeling. Owing to functions of Caspase 1 in im mune cells, we first investigated whether MILH induced Caspase 1 ac tivation was associated with Il1 $\beta$ secretion (Fig. 5a). Our results show that, in INR1G9 CCK2R cells which were LPS primed or not, MILH did not increase Il1 $\beta$ secretion relative to control cells. In contrast, in LPS primed Thp1 macrophages, which were used as reference cells for Il1 $\beta$ processing and secretion, levels of Il1 $\beta$ secretion were increased by $27.7 \pm 3.2$ fold over basal value. The levels of $111 \beta$ secretion by INR1G9 CCK2R cells were very low ( $<2 \mathrm{pg} / \mathrm{mg}$ of cell proteins) as was that of Pro Il1 $\beta$ expression, comparatively to macrophages cells (Fig. 5b). Hence, MILH induces Caspase 1 dependent cell death without activating the Caspase 1 pro inflammatory response in the endocrine tumoral INR1G9 CCK2R cells. However, we could not exclude that pro inflammatory response could be activated by MILH in cancer cells ex pressing higher level of Pro Il1 $\beta$.

Then, we characterized DNA fragmentation caused by MILH using TUNEL assay which consists in the incorporation of fluorescent dUTP (deoxyuridine triphosphate) into free $3^{\prime}$ hydroxyl termini generated by genomic DNA fragmentation (Fig. 5c). Results indicate that, after $6 \mathrm{~h}$ of AMF exposure, DNA fragmentation increased by $3.4 \pm 0.5$ fold re lative to control cells $(22.9 \pm 3.8 \%$ vs $8.5 \pm 1.4 \%$ of positive cells $)$. Of note, DNA fragmentation induced by MILH was less abundant than that caused by staurosporine or by $42{ }^{\circ} \mathrm{C}$ water bath $(40.1 \pm 4.9 \%$ or $52.6 \pm 14.0 \%$ of positive cells, respectively). Secondly, we char acterized the type of DNA fragmentation caused by MILH (Fig. 5d). In contrast to staurosporine treatment which provoked regular inter nu cleosomic DNA fragmentation characterized by DNA ladder [37], MILH did not induce the formation of the characteristic laddering pattern associated with apoptosis. In conclusion, our results show that MILH induced a non apoptotic Caspase 1 dependent cell death related to pyroptosis which occurred without Il1 $\beta$ secretion and which was characterized by the formation of TUNEL positive cells without ex hibiting a laddering pattern $[37,38]$. 

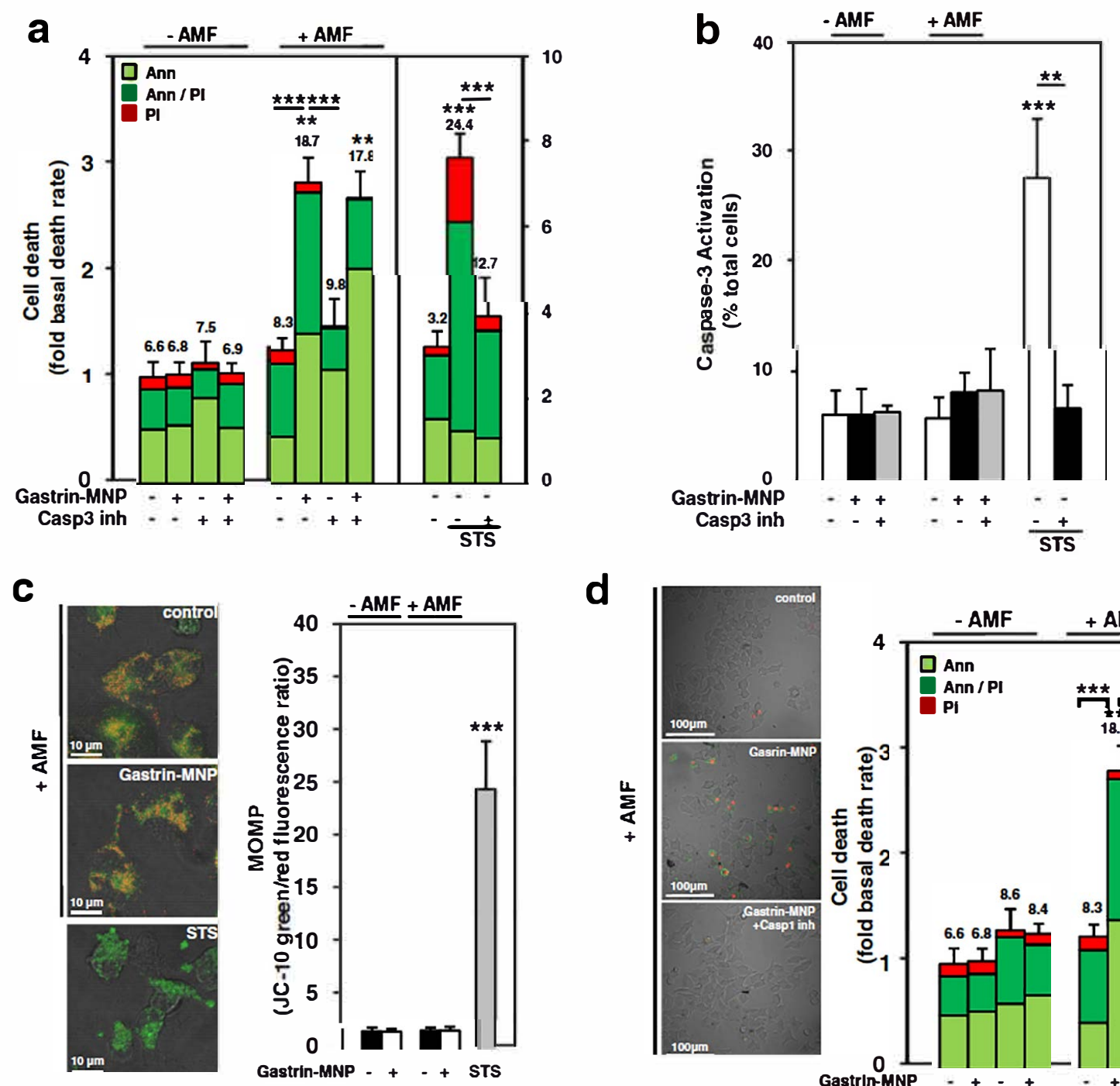

d
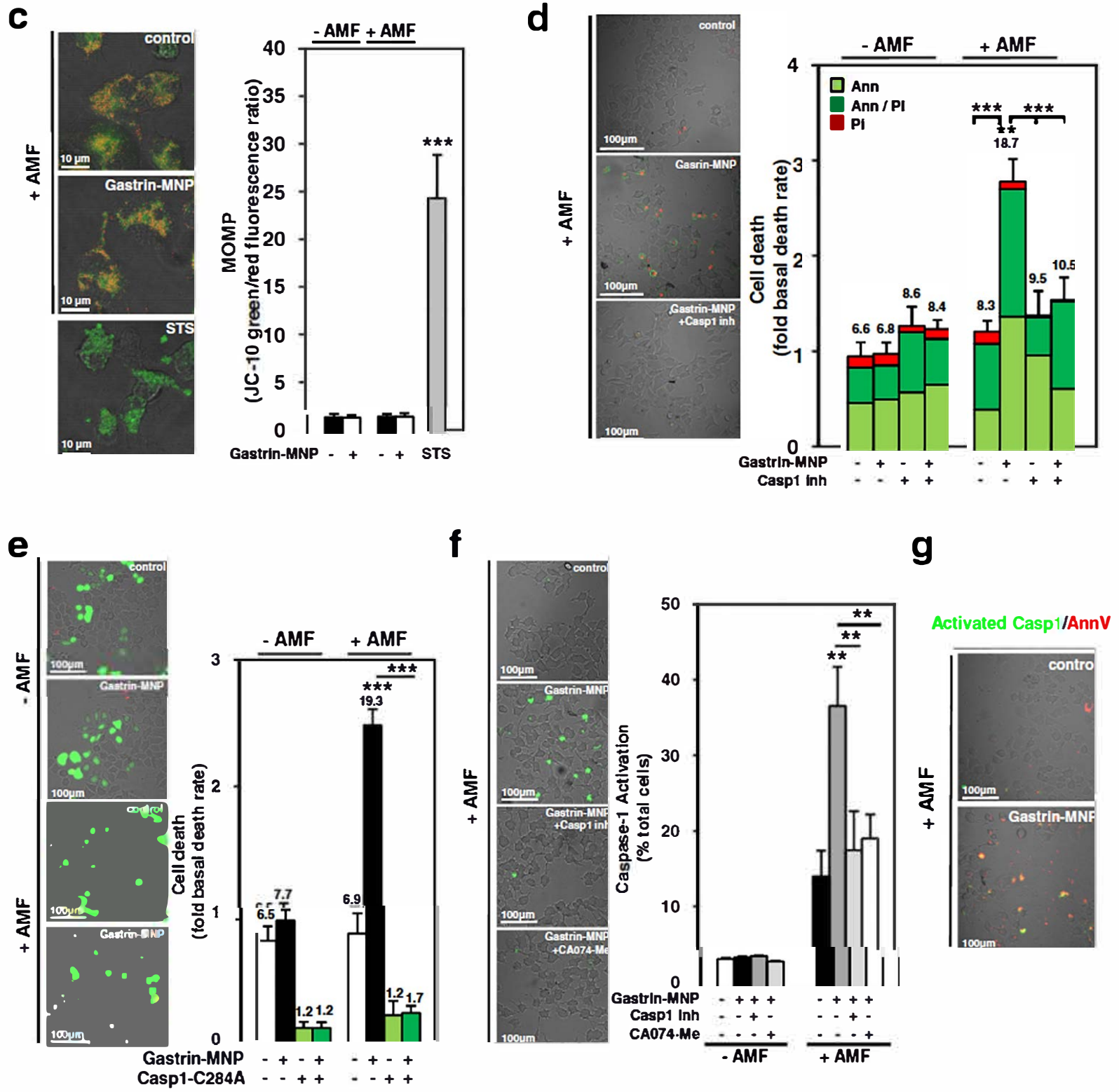

(coption on next page) 
Fig. 4. Cell death induced by MLH is mediated tbrough a non-apopetic Caspase-1 signaling path way which is dependent on CathB activity.

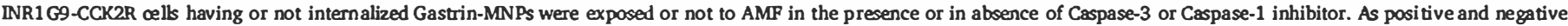

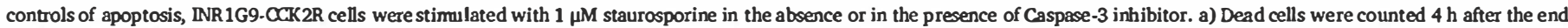

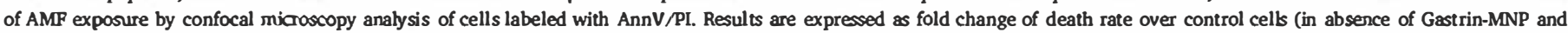

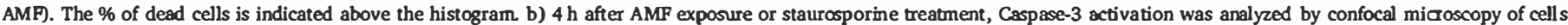

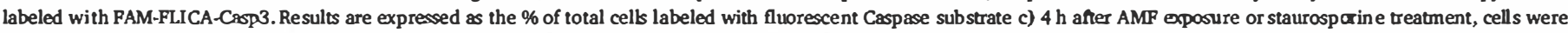

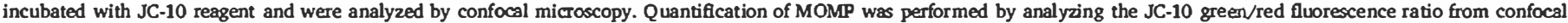

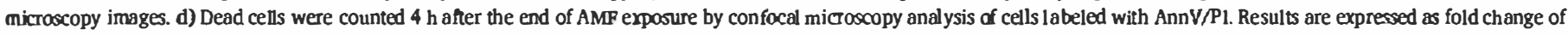

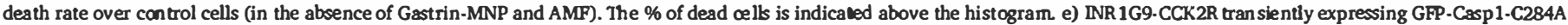

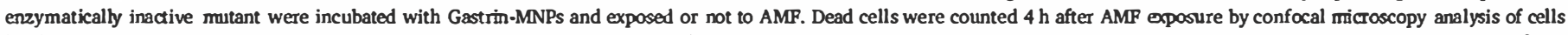

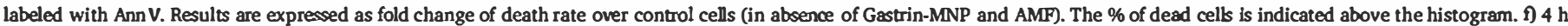

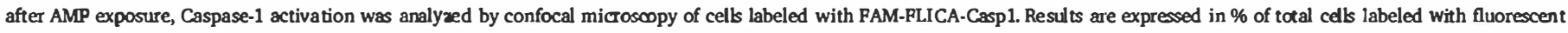

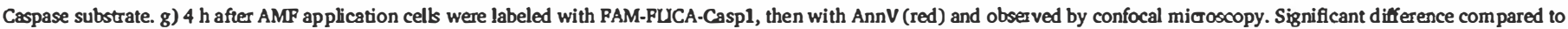

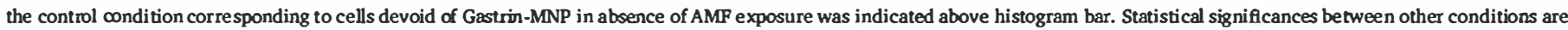

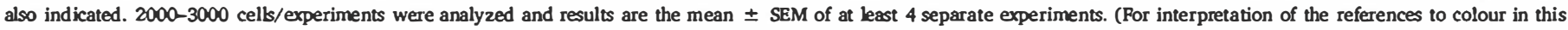
Ggure legend, the reader is referred to the web version of this article.)

\subsection{Gastrin grafted MNPs intuces the death of cells expressing the CCK2R by MILH}

The preceding experiments analyzed the effects and mechanisms of MIIH applied to the pancreatic endocrine tumor cells INR1G9 CCK2R. Herein, we extended the experiments to two other tumor cell lines, the gastric cell line AGS CCK2R and the pancreatic cell line AR4 2J, which express the CCK2R at low levels $\left(\sim 100 \mathrm{fmol} / 10^{6}\right.$ cells $)$ [39]. Cell sur vival data show that, $24 \mathrm{~h}$ after AMF exposure, MIIH has eradicated $22.0 \pm 4.5 \%$ of AGS CCK2R cells and $23.1 \pm 1.3 \%$ of AR4 $2 \mathrm{~J}$ cells presenting Gastrin MNPs mainly in their lysosomes (Fig. 6a, S12). In the same conditions, $56.6 \pm 4.0 \%$ and $42.7 \pm 6.4 \%$ of HEK CCK2R

a

b
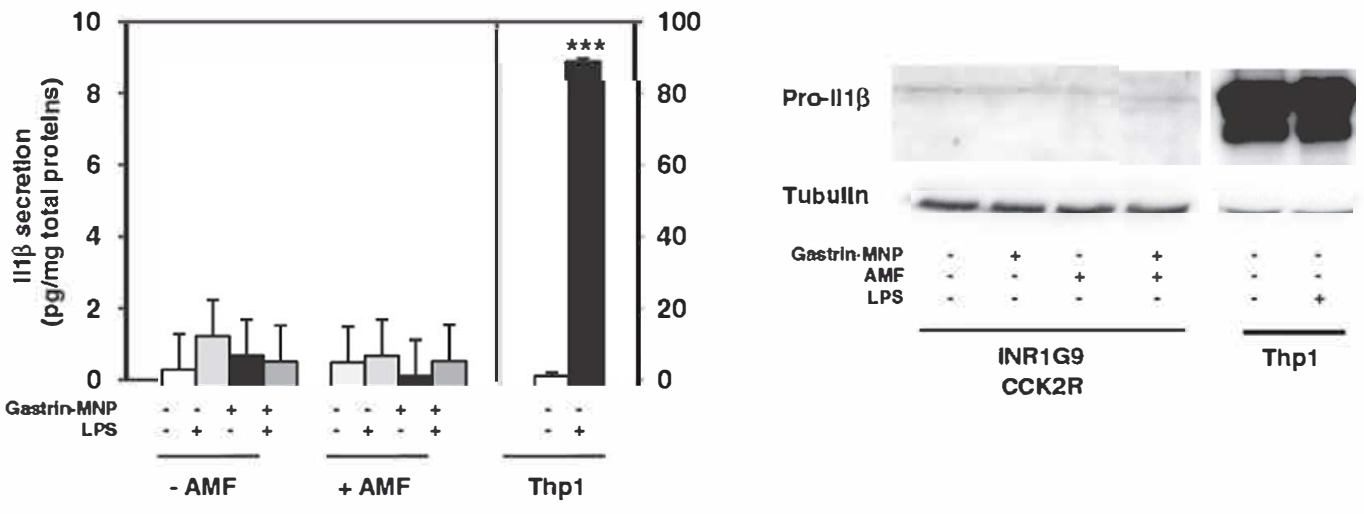

C
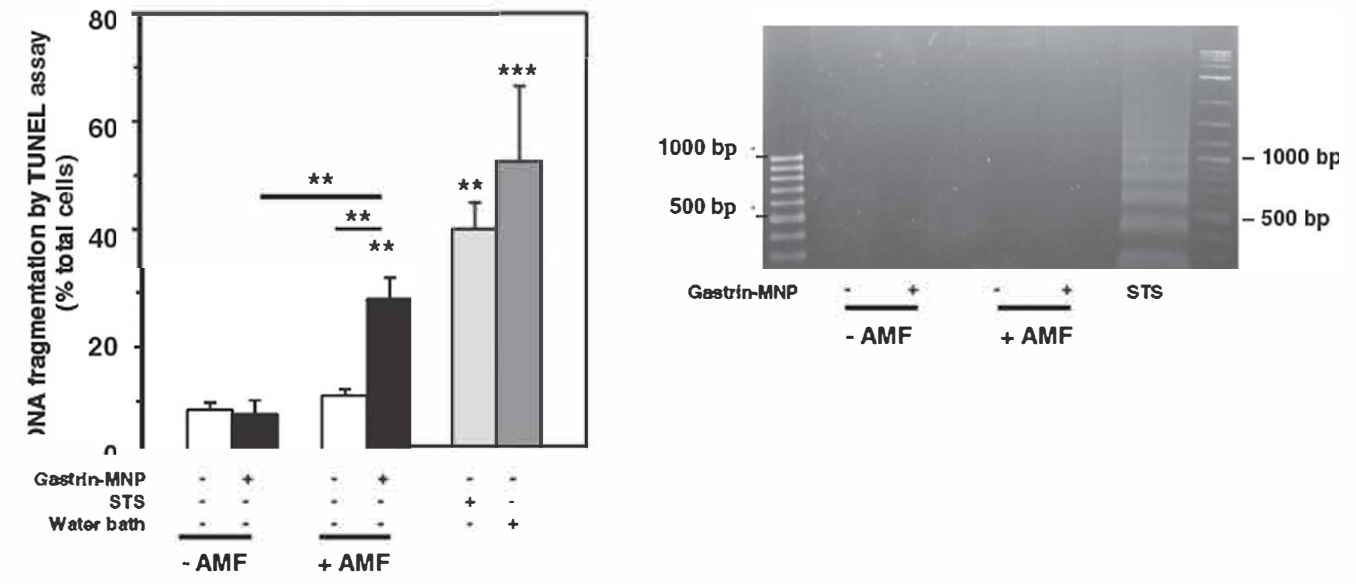

Fig. 5. MILH triggers a non-apoptotic cell death mechanism related to pyroptosis.

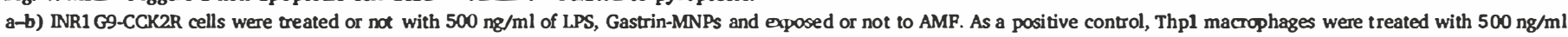

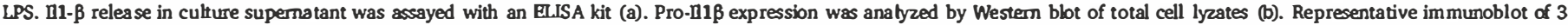

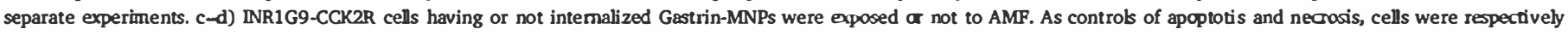

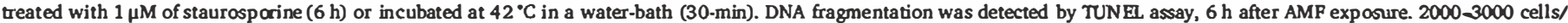

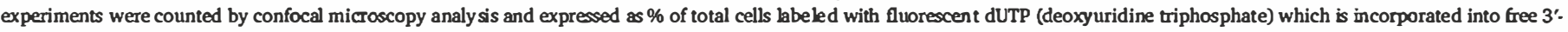

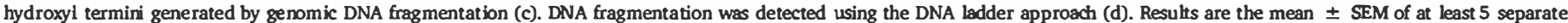

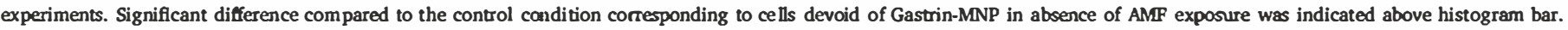
Statistical significances between other conditions are also indicated. 

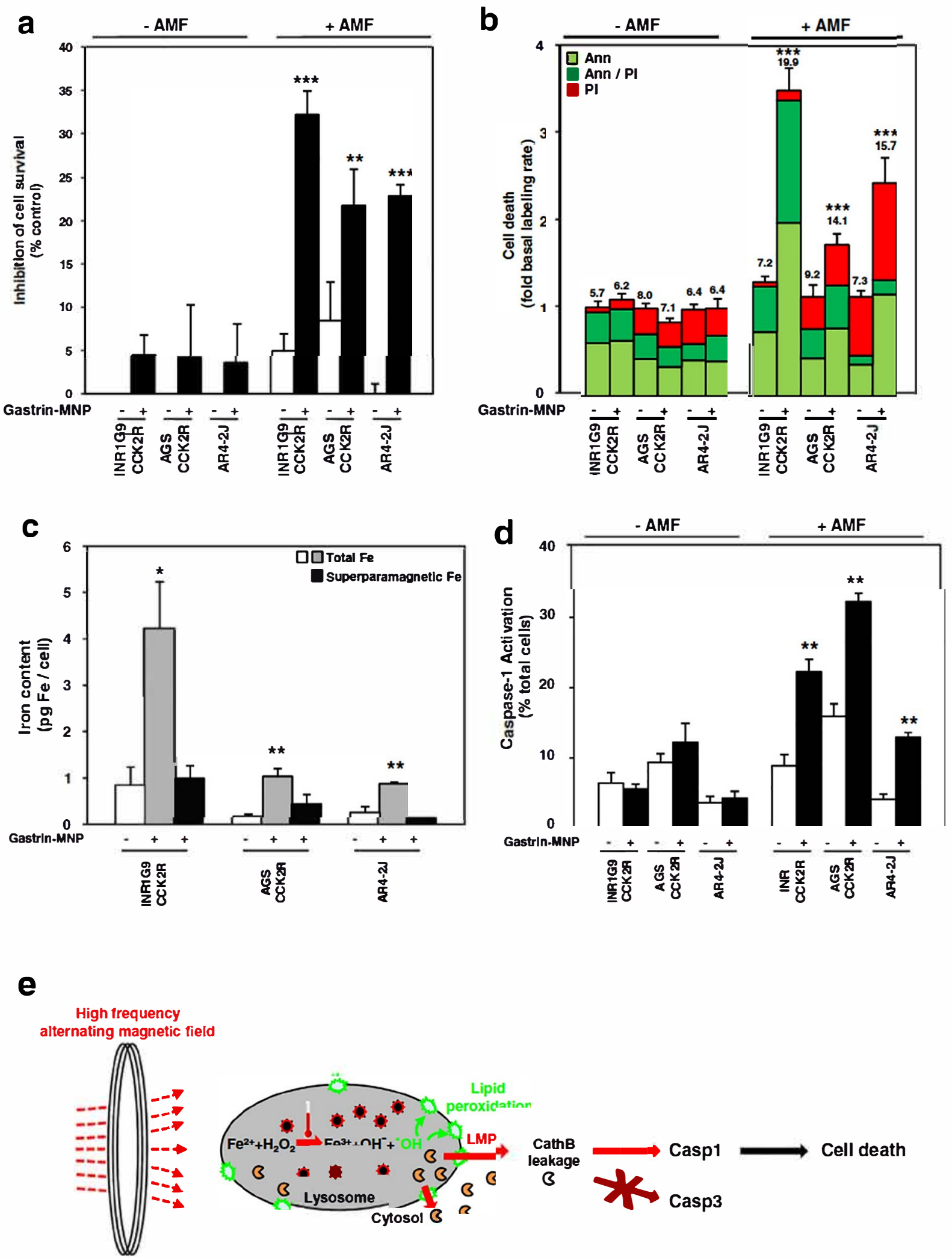

(coption on next page) 
Fig. 6. MILH induces the death and activates Caspase-1 in different cancer cells.

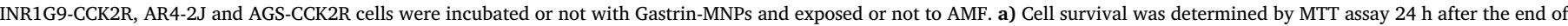

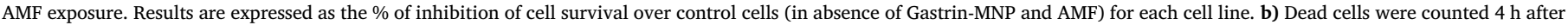

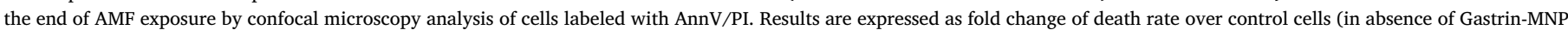

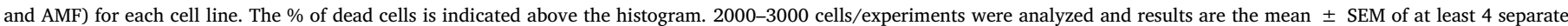

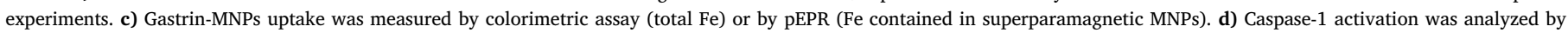

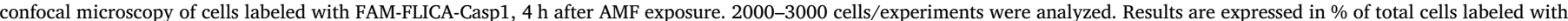

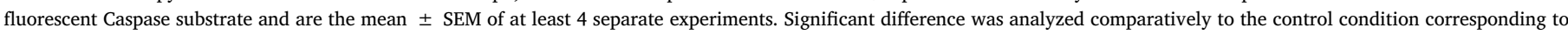

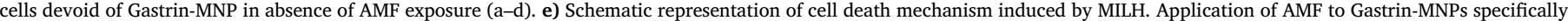

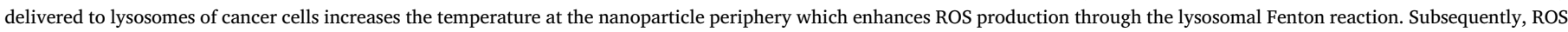

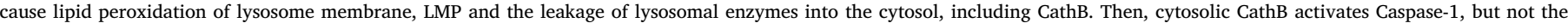
apoptotic Caspase-3, to induce the death of cancer cells.

cells were killed using $16 \mu \mathrm{g} / \mathrm{ml}$ or $1 \mu \mathrm{g} \mathrm{Fe} / \mathrm{ml}$ of Gastrin MNP re spectively (Fig. S13a b). Ann/PI labeling confirmed that MILH induced cell death was detectable $4 \mathrm{~h}$ post AMF (Fig. $6 \mathrm{~b}$ ) and dead cells were more often labeled with PI in AGS CCK2R and AR4 $2 \mathrm{~J}$ cells than in INR1G9 CCK2R cells. MILH also triggered cell death in the non tumoral embryonic kidney cell overexpressing the CCK2R (HEK CCK2R: $2.0 \pm 0.2 \mathrm{pmol} / 10^{6}$ cells) previously used to characterize uptake and cellular trafficking of Gastrin MNPs (Fig. S13c) $[4,40]$.

Determination of the uptake of Gastrin MNPs by the different cells indicates that receptor mediated uptake of MNPs by AGS CCK2R, AR4 $2 \mathrm{~J}$ and INR1G9 CCK2R cells was $0.83 \pm 0.23,0.60 \pm 0.13$ and $3.38 \pm 0.74 \mathrm{pg}$ of $\mathrm{Fe} /$ cell which corresponded to $0.52 \pm 0.22$, $0.14 \pm 0.02$ and $1.07 \pm 0.28 \mathrm{pg}$ of magnetic Fe/cell, respectively, as measured by pEPR, after $24 \mathrm{~h}$ of intracellular accumulation (Fig. 6c). Of note, in HEK CCK2R cells, Gastrin MNPs uptake was evaluated to be $4.01 \pm 0.40$ and $1.48 \pm 0.22 \mathrm{pg}$ of total and magnetic Fe/cell, re spectively (Fig. S13d).

We finally assessed that the signaling pathway involved in MILH induced cell death in AGS CCK2R, AR4 2J and HEK CCK2R cells was similar to that identified in INR1G9 CCK2R. Firstly, no significant Caspase 3 activation could be detected in the 3 cell lines, similarly to INR1G9 CCK2R cells (Fig. S13e, S14). Secondly, MILH increased Caspase 1 activation, $4 \mathrm{~h}$ after AMF exposure, by $3.5 \pm 0.1,3.6 \pm 0.2$ and $6.2 \pm 0.6$ fold in AGS CCK2R, AR4 $2 \mathrm{~J}$ and HEK CCK2R respec tively, similarly to INR1G9 CCK2R cells (Fig. 6d, S13f).

These above results demonstrate that MILH is effective in inducing the death of cancer cells from three different types of cancer (pancreatic endocrine, pancreatic exocrine and gastric) even if the targeted re ceptor is expressed at low levels and if minute amounts of Gastrin MNPs are internalized. Moreover, in the three cancers, as well as in HEK cells, MILH induced cell death occurs through activation of Caspase 1 and without activation of Caspase 3, indicating that MILH triggers a non apoptotic cell death pathway following lysosome damage which is de pendent on Caspase 1 activation.

\section{Discussion}

Following the publication of the proof of concept of anti cancer nanotherapy using ligand grafted MNPs specifically internalized via cell surface receptor, this study gained insight into the mechanisms at the origin of cell death induced by MILH (Fig. 6e). Using Gastrin MNPs which specifically target lysosomes of tumoral cells expressing the CCK2R as a killing agent, we demonstrate that tumor cell death induced by MILH occurs through a Caspase 1 dependent mechanism, but not an apoptotic signaling pathway, since Caspase 3 was not activated. This mechanism of MILH induced cell death was demonstrated in pancreatic endocrine tumor cells as well as in gastric and pancreatic exocrine tumor cells expressing the CCK2R.

MILH first upregulates the catalysis of ROS production through the Fenton type reaction within lysosomes which subsequently causes lipid peroxidation, followed by LMP and the leakage of lysosomal content into the cytosol. Among the lysosomal enzymes, CathB plays a critical role in cell death and activates Caspase 1. Thus, MILH induced tumor cell death can be related to pyroptosis mainly described in macro phages, but rarely in epithelial cells $[35,41,42]$. Indeed, we showed that dead cells present AnnV and/or PI positive labelings and irregular DNA fragmentation (TUNEL positive staining without laddering pattern) as previously observed in pyroptotic macrophages $[37,38,43]$. However, whilst Caspase 1 dependent cell death by pyroptosis in macrophages is usually associated with pro inflammatory responses resulting from Caspase 1 cleavage of Il $1 \beta$ and 18 , MILH did not increase Il $1 \beta$ clea vage. These last results are in line with recent studies showing that Caspase 1 can induce pyroptotic cell death independently of Il1 $\beta$ processing [44 46]. On the other hand, Pro Il1 $\beta$ is expressed at low levels in our tumor cell model. Thus, we cannot not exclude that pro inflammatory response would be activated by MILH in cancer cells expressing higher level of Pro IL $1 \beta$.

Our current knowledge about Caspase 1 indicates that Caspase 1 is synthesized as a cytosolic, inactive, monomeric zymogen (pro Caspase 1) that is thought to be activated by dimerization and autoproteolytic processing, resulting in generation of large and small subunits (called p20 and p10) of the catalytically active enzyme [47,48]. This activation step is preceded by recruitment of Pro Caspase 1 into inflammasomes, which are multiprotein signaling complexes. Furthermore, a direct processing of Caspase 1 by CathB $[49,50]$ or an indirect mechanism of activation through CathB induced activation of inflammasome com plexes [41,50 52] were reported. In the current study of MILH induced cell death, CathB activation is critical for Caspase 1 activation and tumor cell death indicating that one of these two mechanisms may function, but this remains to be determined more precisely.

\section{Conclusion}

The present study provides essential new data on the mechanism whereby targeted MNPs induce the death of tumor cells when exposed to a high frequency magnetic field. The central role of the Fenton re action that produces ROS within lysosomes, together with that of CathB and Caspase 1, represent the key elements which are the basis for the optimization of Magnetic Intra Lysosomal Hyperthermia or MILH strategies to kill cancer cells and their future developments as an anti tumoral option.

Supplementary data to this article can be found online at https:// doi.org/10.1016/j.jconrel.2017.11.050.

\section{Acknowledgements}

PC and VG performed and analyzed studies of ROS production, lipid peroxidation, molecular thermometry, lysosome membrane permeabi lization, Caspases activation and cell death. PJ and BP performed and analyzed DNA fragmentation and Il $1 \beta$ secretion studies. JC conceived the miniaturized electromagnet. NH and MG carried out magnetic field exposure using miniaturized electromagnet or magnetic inductor. VG, DF and JC wrote the manuscript.

We thank Cellular Imaging Facility Rangueil and Flow Cytometry platform of I2MC/INSERM for the excellent technical support. This research was partly funded by Ligue Nationale Contre le Cancer and 
Ligue Régionale Contre le Cancer (comité 31) (No. 9FI11704PPZM), the European Community's Seventh Framework Programm under grant agreement no. 262943 "MULTIFUN" and INSERM grant no. PC201310. We greatly appreciate the gift of plasmids encoding GFP CathB WT and GFP CathB C29A from Klaudia Brix (Jacobs University Bremen, Germany) and pMSCV2.2 IRES GFP Caspase 1 C284A from Petr Broz (University of Basel, Switzerland).

The following are the supplementary data related to this article.

\section{Conflicts of interest}

None.

\section{References}

[1] S. Kachalaki, M. Ebrahimi, L. Mohamed Khosroshahi, S. Mohammadinejad, B. Baradaran, Cancer chemoresistance; biochemical and molecular aspects: a brief overview, Eur. J. Pharm. Sci. 89 (2016) 20-30.

[2] L. Groth-Pedersen, M. Jaattela, Combating apoptosis and multidrug resistant cancers by targeting lysosomes, Cancer Lett. 332 (2013) 265-274.

[3] U. Repnik, M. Hafner Cesen, B. Turk, Lysosomal membrane permeabilization in cell death: concepts and challenges, Mitochondrion 19 (Pt A) (2014) 49-57.

[4] C. Sanchez, D. El Hajj Diab, V. Connord, P. Clerc, E. Meunier, B. Pipy, B. Payre, R.P. Tan, M. Gougeon, J. Carrey, V. Gigoux, D. Fourmy, Targeting a G-proteincoupled receptor overexpressed in endocrine tumors by magnetic nanoparticles to induce cell death, ACS Nano 8 (2014) 1350-1363.

[5] M. Domenech, I. Marrero-Berrios, M. Torres-Lugo, C. Rinaldi, Lysosomal membrane permeabilization by targeted magnetic nanoparticles in alternating magnetic fields, ACS Nano 7 (2013) 5091-5101.

[6] M. Creixell, A.C. Bohorquez, M. Torres-Lugo, C. Rinaldi, EGFR-targeted magnetic nanoparticle heaters kill cancer cells without a perceptible temperature rise, ACS Nano 5 (2011) 7124-7129.

[7] D. Fourmy, J. Carrey, V. Gigoux, Targeted nanoscale magnetic hyperthermia challenges and potentials of peptide-based targeting, Nanomedicine (Lond.) 10 (2015) 893-896.

[8] J.C. Reubi, Targeting CCK receptors in human cancers, Curr. Top. Med. Chem. 7 (2007) 1239-1242.

[9] A.C. Silva, T.R. Oliveira, J.B. Mamani, S.M. Malheiros, L. Malavolta, L.F. Pavon, T.T. Sibov, E. Amaro Jr., A. Tannus, E.L. Vidoto, M.J. Martins, R.S. Santos, L.F. Gamarra, Application of hyperthermia induced by superparamagnetic iron oxide nanoparticles in glioma treatment, Int. J. Nanomedicine 6 (2011) 591-603.

[10] R.P. Tan, J. Carrey, M. Respaud, Magnetic hyperthermia properties of nanoparticles inside lysosomes using kinetic Monte Carlo simulations: influence of key parameters and dipolar interactions, and evidence for strong spatial variation of heating power, Phys. Rev. B 90 (2014).

[11] A. Gewies, S. Grimm, Cathepsin-B and cathepsin-L expression levels do not correlate with sensitivity of tumour cells to TNF-alpha-mediated apoptosis, Br. J. Cancer 89 (2003) 1574-1580.

[12] W. Li, X.M. Yuan, G. Nordgren, H. Dalen, G.M. Dubowchik, R.A. Firestone, U.T. Brunk, Induction of cell death by the lysosomotropic detergent MSDH, FEBS Lett. 470 (2000) 35-39.

[13] T. Uchimoto, H. Nohara, R. Kamehara, M. Iwamura, N. Watanabe, Y. Kobayashi, Mechanism of apoptosis induced by a lysosomotropic agent, L-Leucyl-L-leucine methyl ester, Apoptosis 4 (1999) 357-362.

[14] T. Cirman, K. Oresic, G.D. Mazovec, V. Turk, J.C. Reed, R.M. Myers, G.S. Salvesen, B. Turk, Selective disruption of lysosomes in HeLa cells triggers apoptosis mediated by cleavage of Bid by multiple papain-like lysosomal cathepsins, J. Biol. Chem. 279 (2004) 3578-3587.

[15] S. Leung-Theung-Long, E. Roulet, P. Clerc, C. Escrieut, S. Marchal-Victorion, B. RitzLaser, J. Philippe, L. Pradayrol, C. Seva, D. Fourmy, M. Dufresne, Essential interaction of Egr-1 at an islet-specific response element for basal and gastrin-dependent glucagon gene transactivation in pancreatic alpha-cells, J. Biol. Chem. 280 (2005) 7976-7984.

[16] F. Watson, R.S. Kiernan, D.G. Deavall, A. Varro, R. Dimaline, Transcriptional activation of the rat vesicular monoamine transporter 2 promoter in gastric epithelial cells: regulation by gastrin, J. Biol. Chem. 276 (2001) 7661-7671.

[17] V. Connord, P. Clerc, N. Hallali, D. El Hajj Diab, D. Fourmy, V. Gigoux, J. Carrey, Real-time analysis of magnetic hyperthermia experiments on living cells under a confocal microscope, Small 11 (2015) 2437-2445.

[18] T. Kurz, B. Gustafsson, U.T. Brunk, Intralysosomal iron chelation protects against oxidative stress-induced cellular damage, FEBS J. 273 (2006) 3106-3117.

[19] P. Ghosh, C. Kumar, A.N. Samanta, S. Ray, Comparison of a new immobilized Fe3 + catalyst with homogeneous $\mathrm{Fe} 3+\mathrm{H} 2 \mathrm{O} 2$ system for degradation of 2,4-dinitrophenol, J. Chem. Technol. Biotechnol. 87 (2012) 914-923.

[20] N.D. Yang, S.H. Tan, S. Ng, Y. Shi, J. Zhou, K.S.W. Tan, W.S.F. Wong, H.M. Shen, Artesunate induces cell death in human cancer cells via enhancing lysosomal function and lysosomal degradation of ferritin, J. Biol. Chem. 289 (2014) 33425-33441.

[21] P. Boya, G. Kroemer, Lysosomal membrane permeabilization in cell death, Oncogene 27 (2008) 6434-6451.

[22] H. Cable, J.B. Lloyd, Cellular uptake and release of two contrasting iron chelators, J.
Pharm. Pharmacol. 51 (1999) 131-134.

[23] S. Dikalov, Cross talk between mitochondria and NADPH oxidases, Free Radic. Biol. Med. 51 (2011) 1289-1301.

[24] F. Mazuel, A. Espinosa, N. Luciani, M. Reffay, R. Le Borgne, L. Motte, K. Desboeufs, A. Michel, T. Pellegrino, Y. Lalatonne, C. Wilhelm, Massive intracellular biodegradation of iron oxide nanoparticles evidenced magnetically at single-endosome and tissue levels, ACS Nano 10 (2016) 7627-7638.

[25] F. Mazuel, A. Espinosa, G. Radtke, M. Bugnet, S. Neveu, Y. Lalatonne, G.A. Botton, A. Abou-Hassan, C. Wilhelm, Magneto-thermal metrics can mirror the long-term intracellular fate of magneto-plasmonic nanohybrids and reveal the remarkable shielding effect of gold, Adv. Funct. Mater. 27 (2017).

[26] R.J. Wydra, P.G. Rychahou, B.M. Evers, K.W. Anderson, T.D. Dziubla, J.Z. Hilt, The role of ROS generation from magnetic nanoparticles in an alternating magnetic field on cytotoxicity, Acta Biomater. 25 (2015) 284-290.

[27] A. Riedinger, P. Guardia, A. Curcio, M.A. Garcia, R. Cingolani, L. Manna, T. Pellegrino, Subnanometer local temperature probing and remotely controlled drug release based on azo-functionalized iron oxide nanoparticles, Nano Lett. 13 (2013) 2399-2406.

[28] H. Huang, S. Delikanli, H. Zeng, D.M. Ferkey, A. Pralle, Remote control of ion channels and neurons through magnetic-field heating of nanoparticles, Nat Nanotechnol. 5 (2010) 602-606.

[29] Y. Xu, J. Wang, X. Song, R. Wei, F. He, G. Peng, B. Luo, Protective mechanisms of CA074-me (other than cathepsin-B inhibition) against programmed necrosis induced by global cerebral ischemia/reperfusion injury in rats, Brain Res. Bull. 120 (2016) 97-105.

[30] T. Nomura, N. Katunuma, Involvement of cathepsins in the invasion, metastasis and proliferation of cancer cells, J. Med. Invest. 52 (2005) 1-9.

[31] B. Turk, J.G. Bieth, I. Bjork, I. Dolenc, D. Turk, N. Cimerman, J. Kos, A. Colic, V. Stoka, V. Turk, Regulation of the activity of lysosomal cysteine proteinases by $\mathrm{pH}$-induced inactivation and/or endogenous protein inhibitors, cystatins, Biol. Chem. Hoppe Seyler 376 (1995) 225-230.

[32] C.S. Pillay, C. Dennison, Cathepsin B stability, but not activity, is affected in cysteine:cystine redox buffers, Biol. Chem. 383 (2002) 1199-1204.

[33] D.J. Buttle, M. Murata, C.G. Knight, A.J. Barrett, CA074 methyl ester: a proinhibitor for intracellular cathepsin B, Arch. Biochem. Biophys. 299 (1992) 377-380.

[34] L. Galluzzi, J.M. Bravo-San Pedro, I. Vitale, S.A. Aaronson, J.M. Abrams, D. Adam, E.S. Alnemri, L. Altucci, D. Andrews, M. Annicchiarico-Petruzzelli, E.H. Baehrecke, N.G. Bazan, M.J. Bertrand, K. Bianchi, M.V. Blagosklonny, K. Blomgren, C. Borner, D.E. Bredesen, C. Brenner, M. Campanella, E. Candi, F. Cecconi, F.K. Chan, N.S. Chandel, E.H. Cheng, J.E. Chipuk, J.A. Cidlowski, A. Ciechanover, T.M. Dawson, V.L. Dawson, V. De Laurenzi, R. De Maria, K.M. Debatin, N. Di Daniele, V.M. Dixit, B.D. Dynlacht, W.S. El-Deiry, G.M. Fimia, R.A. Flavell, S. Fulda, C. Garrido, M.L. Gougeon, D.R. Green, H. Gronemeyer, G. Hajnoczky, J.M. Hardwick, M.O. Hengartner, H. Ichijo, B. Joseph, P.J. Jost, T. Kaufmann, O. Kepp, D.J. Klionsky, R.A. Knight, S. Kumar, J.J. Lemasters, B. Levine, A. Linkermann, S.A. Lipton, R.A. Lockshin, C. Lopez-Otin, E. Lugli, F. Madeo, W. Malorni, J.C. Marine, S.J. Martin, J.C. Martinou, J.P. Medema, P. Meier, S. Melino, N. Mizushima, U. Moll, C. Munoz-Pinedo, G. Nunez, A. Oberst, T. Panaretakis, J.M. Penninger, M.E. Peter, M. Piacentini, P. Pinton, J.H. Prehn, H. Puthalakath, G.A. Rabinovich, K.S. Ravichandran, R. Rizzuto, C.M. Rodrigues, D.C. Rubinsztein, T. Rudel, Y. Shi, H.U. Simon, B.R. Stockwell, G. Szabadkai, S.W. Tait, H.L. Tang, N. Tavernarakis, Y. Tsujimoto, T. Vanden Berghe, P. Vandenabeele, A. Villunger, E.F. Wagner, H. Walczak, E. White, W.G. Wood, J. Yuan, Z. Zakeri, B. Zhivotovsky, G. Melino, G. Kroemer, Essential versus accessory aspects of cell death: recommendations of the NCCD 2015, Cell Death Differ. 22 (2015) 58-73.

[35] L. Galluzzi, I. Vitale, J.M. Abrams, E.S. Alnemri, E.H. Baehrecke, M.V. Blagosklonny, T.M. Dawson, V.L. Dawson, W.S. El-Deiry, S. Fulda, E. Gottlieb, D.R. Green, M.O. Hengartner, O. Kepp, R.A. Knight, S. Kumar, S.A. Lipton, X. Lu, F. Madeo, W. Malorni, P. Mehlen, G. Nunez, M.E. Peter, M. Piacentini, D.C. Rubinsztein, Y. Shi, H.U. Simon, P. Vandenabeele, E. White, J. Yuan, B. Zhivotovsky, G. Melino, G. Kroemer, Molecular definitions of cell death subroutines: recommendations of the Nomenclature Committee on Cell Death 2012, Cell Death Differ. 19 (2012) 107-120.

[36] G. Fantuzzi, C.A. Dinarello, Interleukin-18 and interleukin-1 beta: two cytokine substrates for ICE (caspase-1), J. Clin. Immunol. 19 (1999) 1-11.

[37] E.A. Miao, J.V. Rajan, A. Aderem, Caspase-1-induced pyroptotic cell death, Immunol. Rev. 243 (2011) 206-214.

[38] P.R. Watson, A.V. Gautier, S.M. Paulin, A.P. Bland, P.W. Jones, T.S. Wallis, Salmonella enterica serovars typhimurium and Dublin can lyse macrophages by a mechanism distinct from apoptosis, Infect. Immun. 68 (2000) 3744-3747.

[39] J.L. Scemama, D. Fourmy, A. Zahidi, L. Pradayrol, C. Susini, A. Ribet, Characterisation of gastrin receptors on a rat pancreatic acinar cell line (AR42J). A possible model for studying gastrin mediated cell growth and proliferation, Gut 28 (Suppl) (1987) 233-236.

[40] R. Magnan, B. Masri, C. Escrieut, M. Foucaud, P. Cordelier, D. Fourmy, Regulation of membrane cholecystokinin-2 receptor by agonists enables classification of partial agonists as biased agonists, J. Biol. Chem. 286 (2011) 6707-6719.

[41] W.A. Tseng, T. Thein, K. Kinnunen, K. Lashkari, M.S. Gregory, P.A. D'Amore, B.R. Ksander, NLRP3 inflammasome activation in retinal pigment epithelial cells by lysosomal destabilization: implications for age-related macular degeneration, Invest. Ophthalmol. Vis. Sci. 54 (2013) 110-120.

[42] V. Derangere, A. Chevriaux, F. Courtaut, M. Bruchard, H. Berger, F. Chalmin, S.Z. Causse, E. Limagne, F. Vegran, S. Ladoire, B. Simon, W. Boireau, A. Hichami, L. Apetoh, G. Mignot, F. Ghiringhelli, C. Rebe, Liver X receptor beta activation induces pyroptosis of human and murine colon cancer cells, Cell Death Differ. 21 
(2014) 1914-1924.

[43] M.A. Brennan, B.T. Cookson, Salmonella induces macrophage death by caspase-1dependent necrosis, Mol. Microbiol. 38 (2000) 31-40.

[44] E.A. Miao, I.A. Leaf, P.M. Treuting, D.P. Mao, M. Dors, A. Sarkar, S.E. Warren, M.D. Wewers, A. Aderem, Caspase-1-induced pyroptosis is an innate immune effector mechanism against intracellular bacteria, Nat. Immunol. 11 (2010) 1136-1142.

[45] P. Broz, J. von Moltke, J.W. Jones, R.E. Vance, D.M. Monack, Differential requirement for Caspase-1 autoproteolysis in pathogen-induced cell death and cytokine processing, Cell Host Microbe 8 (2010) 471-483.

[46] B. Guey, M. Bodnar, S.N. Manie, A. Tardivel, V. Petrilli, Caspase-1 autoproteolysis is differentially required for NLRP1b and NLRP3 inflammasome function, Proc. Natl. Acad. Sci. U. S. A. 111 (2014) 17254-17259.

[47] F. Martinon, A. Mayor, J. Tschopp, The inflammasomes: guardians of the body, Annu. Rev. Immunol. 27 (2009) 229-265.

[48] N.A. Thornberry, H.G. Bull, J.R. Calaycay, K.T. Chapman, A.D. Howard,
M.J. Kostura, D.K. Miller, S.M. Molineaux, J.R. Weidner, J. Aunins, et al., A novel heterodimeric cysteine protease is required for interleukin-1 beta processing in monocytes, Nature 356 (1992) 768-774.

[49] K. Vancompernolle, F. Van Herreweghe, G. Pynaert, M. Van de Craen, K. De Vos, N. Totty, A. Sterling, W. Fiers, P. Vandenabeele, J. Grooten, Atractyloside-induced release of cathepsin B, a protease with caspase-processing activity, FEBS Lett. 438 (1998) 150-158.

[50] H. Hentze, X.Y. Lin, M.S. Choi, A.G. Porter, Critical role for cathepsin B in mediating caspase-1-dependent interleukin-18 maturation and caspase-1-independent necrosis triggered by the microbial toxin nigericin, Cell Death Differ. 10 (2003) 956-968.

[51] V. Hornung, F. Bauernfeind, A. Halle, E.O. Samstad, H. Kono, K.L. Rock, K.A. Fitzgerald, E. Latz, Silica crystals and aluminum salts activate the NALP3 inflammasome through phagosomal destabilization, Nat. Immunol. 9 (2008) $847-856$.

[52] Z.L. Newman, S.H. Leppla, M. Moayeri, CA-074Me protection against anthrax lethal toxin, Infect. Immun. 77 (2009) 4327-4336. 